\title{
LIBERDADE DE EXPRESSÃO E SEUS LIMITES NUMA DEMOCRACIA: O CASO DAS ASSIM CHAMADAS “FAKE NEWS" NAS REDES SOCIAIS EM PERÍODO ELEITORAL NO BRASIL
}

\author{
INGO WOLFGANG SARLET ${ }^{1}$ \\ ANDRESSA DE BITTENCOURT SIQUEIRA ${ }^{2}$
}

RESUMO: O recurso às redes sociais e seus instrumentos de comunicação e compartilhamento cada vez mais sofisticados e eficazes, tem ganhado - em relativamente pouco tempo - um espaço imenso no campo dos embates políticoeleitorais, seja como via direta (oficial) da publicidade eleitoral, seja de modo indireto. Nesse contexto, como se verificou de modo particularmente agudo nas últimas eleições presidenciais nos EUA e no Brasil, o uso das assim chamadas fake news (mas também, entre outros, do discurso do ódio), igualmente dominou o cenário nos mais diferenciados meios de comunicação, com destaque, novamente, para o ambiente das redes sociais na internet. Nesse meio tempo, muito se pesquisou e escreveu sobre tais fenômenos, seja na perspectiva da ciência política, seja sob o ângulo da sociologia, psicologia, antropologia, neurociências, teoria da cultura, dentre outros. No caso do Direito, mais especificamente pela ótica do direito constitucional, um dos problemas centrais com o qual se tem ocupado a academia jurídica, mas também os órgãos estatais (designadamente, os poderes Legislativo, Executivo e Judiciário), é o de verificar em que medida o uso de técnicas de desinformação e o manejo das fake news, de modo especial, tem influenciado o pleno funcionamento da Democracia e de suas instituições, como é o caso, das eleições e do respectivo processo, centrais para uma democracia representativa e partidária. Nessa linha, o presente artigo pretende examinar, discutir e avaliar se - e em que medida - o uso de notícias falsas, falaciosas, descontextualizadas, imprecisas etc., aquilo que se tem designado genericamente de fake news, é protegido pelas liberdades de expressão e de informação e, se for o caso, quais os limites que podem ser legitimamente impostos em momentos de pleito eleitoral, de modo a não configurar um impacto desproporcional sobre o princípio democrático e o efetivo funcionamento das respectivas instituições. Outrossim, pretende-se confirmar a tese, já conhecida, não apenas da imprecisão

\footnotetext{
${ }^{1}$ Doutor e Pós-Doutor em Direito, Universidade de Munique. Professor Titular da Escola de Direito e do PPGD da PUCRS. Desembargador aposentado do TJRS. Advogado. E-mail: ingowsarlet@gmail.com.

2 Mestranda em Direito no PPGD da PUCRS. Bolsista integral PROEX vinculada à CAPES. Integrante do Grupo de Estudos e Pesquisa em Direitos Fundamentais (GEDF/CNPq). Advogada. O presente trabalho foi realizado com apoio da Coordenação de Aperfeiçoamento de Pessoal de Nível Superior - Brasil (CAPES) - Código de Financiamento 001.
} 
terminológica, mas também do flagrante reducionismo da figura das fake news para dar conta da complexidade e alcance do fenômeno. Além disso - e esse o objetivo principal - o que se busca é examinar e avaliar, à luz do caso do Brasil e do respectivo marco normativo jurídico-constitucional, mediante recurso ao exemplo da propaganda eleitoral e de sua regulação, como se tem lidado com o uso da desinformação e fake news, quais são os desafios pendentes e em que consistem as possibilidades de equacionamento satisfatório do problema, preservando tanto a liberdade de expressão, quanto o funcionamento das instituições democráticas.

Palavras-Chave: Notícias falsas; Desinformação; Eleições; Liberdade de Expressão e de Informação; Democracia.

ABSTRACT: The use of social networks and their increasingly sophisticated and effective communication and sharing tools has gained - in a relatively short time an immense space in the field of political-electoral clashes, either as a direct (official) way of electoral advertising or in an indirect way. In this context, as was acutely seen in the last US and Brazilian presidential elections, the use of so-called "fake news" (but also, among others, hate speech), also dominated the scenario in the most differentiated media, with emphasis, again, on the Internet social networks environment. In the meantime, much research has been done and written about these phenomena, whether from the perspective of political science, or from the point of view of sociology, psychology, anthropology, neurosciences, cultural theory, among others. In the case of the Law, more specifically from the point of view of Constitutional Law, one of the central problems with which the legal academy, but also the state bodies (namely the Legislative, Executive and Judiciary powers), have been dealing is to verify to what extend the use of disinformation techniques in general and the management of fake news, in particular, has influenced the full functioning of democracy and its institutions, as is the case with elections and the respective process, key to a representative and partisan democracy. Thus, this article intends to examine, discuss and evaluate whether and to what extent - the use of false, misleading, out-of-context, inaccurate news, etc., what has generally been called fake news, is protected by the freedoms of expression and information and, if so, what limits may legitimately be imposed at times of elections, so as not to configure a disproportionate impact on the democratic principle and the effective functioning of the respective institutions. Furthermore, it is intended to confirm the thesis, already known, not only of the terminological imprecision, but also of the blatant reductionism of the fake news figure to account for the complexity and scope of the phenomenon. Besides this and that is the main goal - what is being sought is to examine and evaluate, in light of the case of Brazil and the respective legal-constitutional framework, using the example of electoral propaganda and its regulation, how the use of disinformation and fake news has been dealt, what are the outstanding challenges and what are 
the possibilities of satisfactorily addressing the problem while preserving both freedom of expression and the functioning of democratic institutions.

Keywords: Fake news; Disinformation; Elections; Freedom of Expression and Information; Democracy.

\author{
"Algumas fake news duram para sempre" (Yuval Noah \\ Harari, 21 Lições para o Século 21).
}
"Uma mentira repetida mil vezes torna-se verdade" (Joseph Goebbels).

“O Súdito ideal do governo totalitário não é o nazista convicto nem o comunista convicto, mas aquele para quem já não existe a diferença entre o fato e a ficção (isto é, a realidade e a experiência) e a diferença entre o verdadeiro e o falso (isto é, os critérios do pensamento)" (Hannah Arendt, As Origens do Totalitarismo).

\title{
INTRODUÇÃO
}

O fenômeno, cada vez mais crescente, do compartilhamento desenfreado de notícias falsas, as assim chamadas fake news, assim como de técnicas de desinformação, põe em xeque a legitimidade e correto andamento do pleito eleitoral, acirra sectarismos, instila a divisão social, gera níveis preocupantes de instabilidade política e mesmo representa, cada vez mais, ameaças concretas para a democracia e o funcionamento regular de suas instituições estruturantes.

Nesse mesmo contexto, verifica-se que os debates em torno de quais os limites da liberdade de expressão (aqui em sentido amplo), passaram a assumir novos contornos e acionar novos desafios, não só, mas também para o Direito. Isso se deve ao fato de, embora o recurso à desinformação e a difusão de notícias falsas não constitua, em si, uma novidade, inclusive e em especial no que diz com a sua utilização no embate político-eleitoral, numa era marcada pela onipresente digitalização e em tempos de Big Data, a capacidade de postagem e disseminação em quantidade e com rapidez e alcance há relativamente pouco tempo inimagináveis, tem levado a consequências igualmente impactantes.

Em causa está, ao fim e ao cabo, se e como o Direito é (ou não) capaz de reagir de modo adequado ao fenômeno, ao mesmo tempo combatendo (mediante prevenção e/ou repressão) o abuso no exercício da liberdade de expressão (e de informação), de modo a salvaguardar a funcionalidade do Estado Democrático de 
Direito, sem contudo, ao mesmo tempo, a pretexto de proteger a democracia, fragilizá-la por outra via, limitando de modo desproporcional as liberdades comunicativas e informacionais.

No caso do Brasil, que constitui o mote do presente texto, a exemplo do que havia ocorrido por ocasião das eleições presidenciais norte-americanas, que resultaram na vitória do atual presidente Donald Trump, as últimas eleições gerais, em 2018, não inovaram no que toca ao recurso às mais variadas técnicas de desinformação e das "fake news", posto que, como já sinalizado, mas alcançaram, inclusive e em especial no domínio da internet, níveis assustadores. Isso se deu não apenas em relação aos candidatos à presidência à República, mas foi particularmente mais acentuado em relação aos mesmos, tanto é que não faltaram aqueles que atribuíram a vitória ao candidato que mais fez uso das mídias sociais e sistemas de compartilhamento de mensagens digitais, como é o caso do Twitter e do WhatsApp.

Delimitando o enfoque do trabalho, o objetivo principal é o de identificar e analisar, se e em que medida, o recurso à desinformação, em particular às "fake news" no processo eleitoral, especialmente na esfera das redes sociais online, exige uma reconstrução do respectivo marco regulatório diretamente voltado às eleições, de modo a assegurar, com níveis satisfatórios de eficácia, o combate àquelas fake news que colocam em risco a regularidade e legitimidade das eleições, mantendo ao mesmo tempo o necessário equilíbrio proporcional em relação às liberdades de expressão e de informação de modo a salvaguardar a sua posição preferencial na arquitetura constitucional brasileira.

Nesse sentido, a hipótese que aqui se formula é a de que o estado da arte da regulação jurídica do combate aos abusos discursivos e atentatórios à Democracia veiculados por fake news é, ainda, lacunoso, seja na esfera legislativa, seja ao nível jurisprudencial.

Assim, no que diz com o caminho a percorrer, inicia-se situando o problema no contexto do exercício da liberdade de expressão e de informação na internet, destaque para as mídias sociais, adentrando-se o problema terminológico e conceitual no que diz respeito à categoria das assim chamadas notícias falsas (fake news), analisando suas características e consequências, para, na sequência, tecer algumas considerações sobre o conteúdo e alcance das liberdades (fundamentais) de expressão e de informação. Em um segundo momento, imprescindível analisar, a partir do marco normativo (constitucional e infraconstitucional) vigente no Brasil, as medidas adotadas na esfera normativa e jurisprudencial para o combate às notícias falsas nos ambientes digitais, para, na sequência, discutir, como e em que medida a dogmática dos direitos fundamentais, mediante diálogo com doutrina, legislação e jurisprudência, pode (ou não) oferecer alternativas viáveis para um melhor equacionamento do problema e assegurar tanto elevados níveis de liberdade informacional, quanto ao mesmo tempo salvaguardar de modo eficaz as instituições democráticas. 


\section{LIBERDADE DE EXPRESSÂO E DE INFORMAÇÃO, DESINFORMAÇÃO E REDES SOCIAIS ONLINE NA ERA DA "PÓS-VERDADE"}

Muito embora não seja o caso aqui de desenvolver o ponto, não há como deixar de recordar que o contexto no qual se situa o tema objeto do presente texto - que basicamente gravita em torno do nada novo problema da "verdade e da mentira na política" (ARENDT, 1967) - é particularmente singular em relação às experiências históricas anteriores, onde o recurso à desinformação e à mentira na Política já se revelaram de extrema relevância e de alto impacto, não só, mas especialmente no caso de regimes autoritários e, em especial, totalitários, v.g., os casos do nacionalsocialismo alemão, do regime stalinista soviético, a revolução cultural chinesa, apenas para citar os mais devastadores e mais próximos em termos cronológicos.

Todavia, como igualmente já adiantado, desde o advento da Internet e das assim chamadas mídias sociais, juntamente com os tecnicamente cada vez mais refinados e eficazes meios de postagem e compartilhamento de mensagens, a quantidade, a rapidez e a escala global do fluxo informacional (aqui compreendido em sentido amplo) alcançaram níveis absolutamente sem precedentes e, a cada avanço das tecnologias de informação e comunicação, crescem incessantemente.

Tendo em conta tal cenário, a despeito dos não poucos aspectos positivos gerados pela ampliação quantitativa e qualitativa da digitalização e, em particular, da Internet (a quase imediaticidade nas comunicações, acesso amplo e rápido à informação, facilitação de inúmeras facetas da vida social, econômica e cultural, entre outros), que aqui não é o caso de comentar, não faltam também pontos altamente preocupantes e mesmo alarmantes que tem se avolumado nas últimas três décadas, em especial desde a Internet 2.0, dentre os quais, no que diz respeito ao presente texto, o do abuso das liberdades comunicativas e das suas sequelas, como é o caso do discurso do ódio, da desinformação em geral e das assim chamadas fake news em particular.

Tamanha é a dimensão do fenômeno que há mesmo quem fale em uma sociedade da desinformação (FRANCISCO, 2004), como etapa corrompida da sociedade da informação, ou de uma era da pós-verdade (do inglês post-truth) (DICE, 2017), em que a verdade e sua difusão passa a figurar em segundo plano, cedendo cada vez mais espaço ao apelo à irracionalidade e às emoções ${ }^{3}$ (KAKUTANI, 2018, p. 11).

Ainda nessa perspectiva, no tocante ao problema da erosão da verdade, inclusive na perspectiva axiológica, já não se trata mais "apenas" de notícias falsas, mas de uma falsa ciência (negacionistas de toda ordem), de uma falsa história (como a negação do holocausto), de perfis e mesmo de seguidores falsos nas mídias

\footnotetext{
${ }^{3}$ Ressalta-se que o vocábulo "post-truth" foi considerado pelo Oxford Dictionaries como a palavra do ano, em 2016. Cf. Wang (2016).
} 
sociais (KAKUTANI, 2018, p. 11-12). Estamos, ao fim e ao cabo, "cercados de mentiras e de ficções" (HARARI, 2018, p. 287).

Aliás, já que se está aqui tratando da desinformação e da mentira na perspectiva da política e do processo democrático, calha recordar as palavras de Umberto Eco, no seu texto clássico sobre as características do fascismo - o que vale, em maior ou menor grau, para os movimentos autoritários e/ou populistas em geral - e sua "eternidade", sublinhando-se aqui o apelo ao irracionalismo, no sentido de um culto da ação pela ação, do recurso a uma linguagem marcada por um vocabulário empobrecido e uma gramática simplista, de modo a limitar as possibilidades de um pensamento mais complexo e $\mathrm{crítico}^{4}$ (ECO, 2020, p. 30 e ss).

É, portanto, nessa perspectiva, do uso e do impacto da desinformação e das fake news no âmbito do processo eleitoral democrático e os riscos para a própria democracia que se segue na análise.

\subsection{AS FAKE NEWS E O FENÔMENO DESINFORMACIONAL - TERMINOLOGIA E CONCEITO}

Do ponto de vista terminológico e conceitual, sabe-se que o uso da expressão notícias falsas (do inglês, fake news) não se mostra a mais precisa no contexto do panorama atual no tocante ao fenômeno da desinformação (ZUCKERMAN, 2017, p. 15). Isso, contudo, não quer dizer que se deva proscrever o termo notícias falsas, mas que é preciso especial cuidado na sua definição e delimitação em relação a outros conceitos. Muito embora existam ressalvas - inclusive de autores - em relação ao uso do termo fake news, este será, em nível de um acordo semântico, utilizado no presente texto, dada a sua difusão e popularidade, mas compreendido e manejado de modo adequado.

Para tanto, antes de avançar na análise, e como seu pressuposto, há que realizar um acordo semântico e conceitual a respeito do que se compreende por verdade. Independentemente da existência de outros olhares importantes, adota-se como ponto de partida a lição de Hannah Arendt, que distingue, em termos gerais, dois tipos de verdades: a verdade racional e a verdade factual. A primeira está atrelada ao conhecimento científico como prova-real da verdade, ao passo que a verdade de fato "é estabelecida por testemunhas e repousa em testemunhos; existe apenas à medida em que se fala dela, mesmo que se passe em privado. É política por natureza"5 (ARENDT, 1967, p. 14).

Nesse contexto, assume relevo - em especial no tocante ao que Arendt chama de verdade de fato, a necessidade de abandonar uma perspectiva nietzschiana da verdade, em que ela sempre é decorrente de uma interpretação de alguém sobre determinada situação, porquanto resta evidente o caos gerado no momento em que a verdade e fatos objetivos tornam-se uma questão de perspectiva e ponto de vista,

\footnotetext{
${ }^{4}$ A obra de Umberto Eco, na sua tradução para alemão, com prefácio de Roberto Saviano, inclui dois dos últimos escritos do autor, Il fascismo eterno e Migrazioni e intolleranza, publicados, respectivamente, em 2018 e 2019.

${ }^{5}$ Sobre a verdade científica, v. Machado (2002, p. 241).
} 
principalmente em períodos sensíveis como o é o eleitoral (KAKUTANI, 2018, p. $51,87)$.

Assim, imperioso que se estabeleçam limites conceituais que não alarguem o alcance dos termos linguísticos (enunciados semânticos) que caracterizam o fenômeno das assim chamadas fake news, para que, ao fim e ao cabo, a sua regulação pelo, em especial na esfera jurídica, posto que a maior ou menor elasticidade terminológica e conceitual implica a possibilidade de maior ou menor restrição às liberdades de expressão e de informação, à feição, aliás, do que ocorre quando se trata de uma definição mais ampla ou mais restrita de discurso do ódio, apenas para referir um fenômeno próximo, embora em parte autônomo.

Feitas tais constatações, cabe assentar que o vocábulo "notícia falsa" (do inglês, fake news), de modo geral se faz alusão à criação de uma esfera falaciosa acerca de algo ou alguém, de onde resulta que o termo não seja suficiente para explicar e abarcar toda a complexidade do fenômeno da desinformação. Com efeito, o termo "notícia falsa" é largamente utilizado na medida em que essas informações são veiculadas em formato de notícia (BALEM, 2017, p. 3) - porquanto notícias são supostamente - e normativamente - baseadas na verdade (TANDOC JR; LIM; LING, 2018, p. 140, para efetivamente ludibriar o público receptor da informação. Já o termo "falsa" (no inglês, fake) remete, numa primeira mirada, à tradução da expressão false, mas, em realidade, provém da tradução de fake, no sentido de que se trata de uma informação falsa que se apresenta de tal modo para esconder o seu caráter de falsidade (ALLCOTT; GENTZKOW, 2017, p. 211).

A expressão "fake news", assim, é comumente utilizada para ilustrar uma variada gama de informações: erros não intencionais, rumores sem origem notícia exata, teorias da conspiração, sátiras, distorções da realidade, falsas afirmações de políticos (ALLCOTT; GENTZKOW, 2017, p. 214), paródias, conteúdo distorcido, conteúdo fabricado, falsas conexões, conteúdo manipulado (WARDLE, 2017), publicidade enganosa, propaganda ideológica (TANDOC JR; LIM; LING, 2018, p. 141-147). No entanto, deve haver melhor delimitação do alcance da expressão. Conforme bem aponta Pereira da Silva, exemplificativamente, as então chamadas fake news não se confundem com os casos de leak(ing), spin(ning), clickbait, e as bullshit news (PEREIRA DA SILVA, 2017)6.

\footnotetext{
${ }^{6}$ O leaking, está relacionado ao vazamento de dados, a priori em sigilo, que são liberados, mediante falha ou fraude, para o público. No spin, ainda que este não seja considerado efetivamente uma mentira, os fatos são moldados de modo a adaptar-se ao público que irá entrar em contato com a informação. Dito de outro modo, no spin transmite-se a informação descrita de determinado modo para agradar (ou desagradar) um grupo específico. Já o clickbait (no português, isca de cliques), consiste numa técnica para chamar atenção do usuário na internet na qual retira-se a acuracidade e qualidade da informação veiculada, sendo comuns em miniaturas em redes sociais com vídeos. Por fim, as bullshit news são aquelas notícias irrelevantes que tentam chamar atenção do leitor, descrita de tal modo a induzir o leitor - por suas convicções pessoais - a distorcer a realidade. Cf. mais detalhes em Pereira da Silva (2017).
} 
Aqui, portanto, para efeitos do presente texto, o termo "fake news" ligeiramente se aproxima dos já conhecidos boatos (SUNSTEIN, 2010), dos quais, contudo, se diferencia tanto pela razão de as fake news terem se adaptado ao desenvolvimento da tecnologia e dos meios comunicativos ${ }^{7}$ e, com isso, aptas a serem disseminadas instantaneamente, como também pela característica de as fake news necessariamente estarem em determinado contexto (in casu, o eleitoral) com o objetivo de criar uma esfera falaciosa sobre algo ou alguém, de modo a enganar o destinatário da mensagem inverídica.

Outro ponto a destacar, já nesta quadra, é que existe uma variada gama de motivos que levam à veiculação, muitas vezes desenfreada, de desinformações: financeiro, com o ganho de lucros; político-eleitoral, objetivando a eleição de um político eleger-se mediante recurso ao falseamento da verdade ou outros expedientes similares, de modo a impedir a eleição de adversários e/ou promover a própria; social, com a criação de grupos coesos que divulguem essas informações; psicológico, visando ao prestígio e reforço dos demais (WARDLE, 2017, p. 5), ensejando uma série de consequências, tais como como a "influência de correntes de opinião; indução de metas de políticas públicas; reforço de vínculos de identificação coletiva e; até mesmo, depreciação da imagem de uma coletividade ou segmento social, étnico ou racial" (BALEM, 2017, p. 3), ademais da possibilidade de disseminação e mesmo instigação do ódio e da violência (SUNSTEIN, 2010, p. 125; BALEM, 2017, p. 5).

Nessa perspectiva, há quem defina três esferas de desinformação. A primeira delas, a dis-information, é a informação falsa e que é veiculada e difundida com o escopo de violar a dignidade de determinada pessoa, grupo ou contingente social; pode-se falar, ainda, em mis-information, que consiste na notícia falsa propriamente dita, já que é, de fato, inverídica, mas não tem a finalidade de causar prejuízos a terceiros; além disso, existe a assim chamada mal-information que é relacionada à informação que, apesar de ter base na realidade, tem o condão de violar a esfera de direitos de determinada "pessoa, organização ou país" (UNIÃO EUROPEIA, 2017; WARDLE, 2017, p. 20).

Note-se que a desordem informacional (information disorder) pode ser tanto falsa, incluindo a mis-information e a dis-information, quanto danosa, beste caso incluindo a mal-information e a dis-information. A mis-information, essencialmente falsa, envolve a dissimulada conexão entre fatos e o conteúdo enganoso, enquanto a malinformation, essencialmente danosa, envolve vazamentos, assédio, discurso de ódio e situações similares. A dis-information, por sua vez, abarca tanto as informações falsas quanto danosas, envolvendo o falseamento do contexto, o conteúdo impostor, a manipulação de conteúdo e a fabricação de conteúdo (WARDLE, 2017). No caso específico das assim designadas fake news, cuida-se da imbricação entre falsidade e danosidade ${ }^{8}$ (LAZER; BAUM; BENKLER, 2018, p. 1094).

\footnotetext{
${ }^{7}$ Sobre a conexão das fake news com sites da internet e redes sociais, v. Klein e Wueller (2017).

${ }^{8}$ É por essa razão que Zuckerman (2017, p. 15) utiliza o termo misdisinfromation.
} 
Outro aspecto de suma relevância e que não pode deixar de ser considerado, é a crescente tendência da utilização das assim chamadas deep fakes (a terminologia advém da combinação entre os vocábulos deep learning (em português, aprendizagem profunda\}e fake news) essencialmente caracterizadas por serem dissimuladas mediante recurso à inteligência artificial, mormente com a combinação de imagem e vídeo, com perfeito alinhamento de voz e expressões faciais, permitindo a fabricação de vídeos falsos (e.g. discursos dissimulados de Chefes de Estado e de Governo, falsos vídeos sexuais de celebridades), cuja minuciosa manipulação praticamente impede o intérprete de identificar que determinada informação não reflete a realidade ${ }^{9}$.

O que se percebe, portanto, é que a utilização de tecnologias cada vez mais sofisticadas agrega não apenas novas dimensões ao fenômeno das fake news, potencializando os seus efeitos de diversas maneiras, ademais de tornar cada vez mais difícil a sua regulação pela ordem jurídica e as instituições responsáveis pela produção e aplicação do Direito.

\subsection{O PROBLEMA DOS EFEITOS DO RECURSO ÀS FAKE NEWS EM RELAÇÃO ÀS LIBERDADES FUNDAMENTAIS E DEMOCRACIA}

Listar e analisar a complexa teia de problemas que dizem respeito ao uso e impacto das fake news representa tarefa hercúlea e que ultrapassa os objetivos do presente texto, de modo que aqui se trata de colacionar os em regra tidos como mais relevantes para as relações entre liberdade de expressão e comunicação, processo eleitoral e democracia, o que não significa que se trate de aspectos comuns, em maior ou menor medida, a outros contextos.

Sem que aqui se esteja a observar uma ordem determinada, inicia-se com a relação entre o fenômeno das fake newws e os processos de polarização política e social, ambos em processo de retroalimentação mútua, como se tem verificado em escala global, mas também e com particular ênfase nas últimas eleições gerais brasileiras de $2018^{10}$.

\footnotetext{
9 O caso paradigmático, no caso das deep fakes, consiste no vídeo produzido por computação gráfica avançada, com base na fala do diretor e ator Jordan Peels, a fim de demonstrar a facilidade que o desenvolvimento tecnológico concedeu às pessoas para que seja possível criar imagens, áudios e vídeos adulterados. Para ler mais sobre o tema, v. Citron e Chesney (2018).

${ }^{10}$ Dentre algumas medidas adotadas pelo TSE, para as últimas eleições ocorridas em 2018, destacase a criação do Conselho Consultivo sobre Internet e Eleições, cujas atribuições estão atreladas ao desenvolvimento de pesquisas da correta aplicação das normas eleitorais, à emissão de pareceres sobre matérias que lhe sejam submetidas pela Presidência do TSE, e à proposição de ações para o aperfeiçoamento dessas normas (BRASIL, 2017a). Além disso, foi assinado um termo de compromisso, proposto em junho de 2018, com 31 partidos políticos, os quais se comprometeram em colaborar contra o compartilhamento de informações falsas nas eleições ocorridas naquele ano (BRASIL, Tribunal Superior Eleitoral, 2018a). Ainda que não conste no rol de partidos, PSTU afirma ter assinado o termo. (RAMALHO, 2018). Ademais, foi também assinado um memorando
} 
O que se pontua, acompanhando SUNSTEIN, é que nesse contexto se intensifica o processo de criação dos assim chamados filtros-bolha (ou, filtros invisíveis) e câmaras de eco $\left(2010\right.$, p. 123) ${ }^{11}$, além da potencialização de heurísticas de indivíduos e grupos, que buscam meramente bloquear a informação completa, de modo a torná-la de mais fácil compreensão, desde que confirmem as suas convicções prévias (SUNSTEIN, 2010, p. 122), o que limita a capacidade retórica e de formação de opinião dos indivíduos. Percebe-se, então, que as fake news situamse em um contexto de apelo emocional e de polarização entre os mais diferentes grupos, quando, em verdade, o debate público deve voltar-se para uma discussão baseada em fatos em comum (KAKUTANI, 2018, p. 19), mediante recurso a uma retórica dialógica e argumentativa.

Além disso, é já sabido que uma relação de confiança fortalece a possibilidade de acreditar-se em uma notícia falsa. Dito de outro modo, um indivíduo tende a tomar uma informação falsa como verdadeira à medida em que essa lhe é enviada por alguém de sua confiança. Por essa razão, apesar de constituírem uma grande quantidade das contas em redes sociais, os robôs sociais (bots, cyborgues), sistemas automáticos de compartilhamento, não são tão eficazes ao transmitir uma informação falsa, uma vez que lhes falta um vínculo de confiança com o receptor da mensagem falaciosa.

Outro aspecto a ser sublinhado, diz respeito ao entusiasmo gerado, num primeiro momento, com o fenômeno da democratização da informação e as people powered-news (PARISER, 2011, p. 52), que podem ser definidas como as informações, em formato de notícia, cujo fluxo em rede é delineado pelos próprios indivíduos que as organizam e as divulgam, mormente nas redes sociais online. No entanto, resulta evidente que o cenário se alterou radicalmente, chegando ao ponto de - não só, mas especialmente - exercer significativa influência em processos eleitorais e na moldagem da opinião pública, contribuindo para a separação das pessoas em grupos bem delimitados, incapazes de conviver com quem professa ideias diferentes das próprias.

Nessa senda, vale sublinhar a lição de FREITAS, segundo a qual "o ceticismo é tão nocivo como o gosto pelas afirmações peremptórias, que tentam desqualificar, estigmatizar e, no limite, banir os que pensam de modo diverso" (2012, p. 136-137), sendo importante perceber a força desse apelo ao subjetivismo, que desdenha o conhecimento científico e especializado (KAKUTANI, 2018, p. 16), como o que,

de entendimento entre a Justiça Eleitoral e o Conselho de Política Institucional e as mídias sociais para coibir a disseminação das então chamadas fake newss, com o Facebook e com o Google, no fim de junho de 2018 (BRASIL, 2018b).

11 Os filtros-bolha estão relacionados à seleção, através de algoritmos, na internet, para que o usuário apenas entre em contato com aquilo que ele é de seu interesse. Por outro lado, câmeras de eco têm relação com grupos formados por meio de interesse compartilhado, nos quais apenas se escuta suas próprias ideias, convicções e valores, sem abrir espaço para se ter contato com outros grupos, que possuem ideias com as quais não há concordância. 
entre outros, marca a narrativa dos movimentos antivacina (antivax) ${ }^{12} \mathrm{e}$, mais recentemente, os grupos que mesmo à vista de todas as evidências, negam-se a acreditar na pandemia da Covid-19, que chegam à cega afirmação de que a doença é resultado de uma conspiração arquitetada em escala global ${ }^{13}$.

Outro ponto que merece destaque nesse contexto, é o da irradiação dos efeitos de informações falsas prolongada no tempo, principalmente quando se utiliza a internet para a sua disseminação. E é nesse ponto, mais uma vez, que se reforça a ligeira, mas ao mesmo tempo densa, diferença entre boatos e fake news, porquanto os primeiros, em que pese sejam "tão antigos quanto a história humana" (SUNSTEIN, 2010, p. 3), uma vez inseridos no contexto da imediata comunicação e do avanço tecnológico, transmudam-se para uma roupagem de fake news, as quais são postadas e compartilhadas na internet, adquirindo, ademais de sua quase onipresença, um efeito duradouro (SUNSTEIN, 2010, p. 5).

Em outras palavras, a possibilidade de multiplicação, replicação e compartilhamento de determinada informação na internet faz com que, mesmo que seja apagada ou retificada, jamais se logre por completo retornar ao estado anterior (LEITER, 2015, p. 167). Com isso, agrava-se o quadro no que diz respeito possibilidade efetivo apagamento (exclusão) de conteúdos na internet e de um respectivo processo de "esquecimento" nesse domínio, não sendo à toa que muito se fala que a internet nunca esquece, contexto, aliás, que demarca a polêmica respeitante ao reconhecimento de um direito humano e fundamental ao esquecimento na internet, que, contudo, aqui não será desenvolvido ${ }^{14}$.

\section{NOTAS SObRE A LIBERDADE DE EXPRESSÃO E DE INFORMAÇÃO, SEUS NOVOS CONTORNOS O PROBLEMA DE SEUS LIMITES NO ÂMBITO DAS REDES SOCIAIS NA INTERNET}

Tudo somado, resulta evidente também o impacto do uso das então chamadas fake news no tocante à configuração de limites à liberdade de expressão e de informação (a pergunta de se e em que medida - quando e como - se pode e deve excluir tais notícias de seu respectivo âmbito de proteção), bem como, em especial no plano do processo eleitoral, os seus efeitos sobre a dimensão subjetiva e objetiva dos direitos, liberdades e garantias fundamentais de natureza política (a querela

\footnotetext{
${ }^{12}$ A Organização Mundial da Saúde (OMS), situando-se no 13ํㅜㄹ Programa Geral de Trabalho, no Relatório sobre os 10 desafios para a saúde mundial em 2019, incluiu, dentre eles, os movimentos antivacina, destacando-se a importância da vacinação para impedir-se 2 a 3 milhões de mortes por ano por doenças evitáveis. O exemplo paradigmático é do sarampo, que registrou um aumento de $30 \%$ no número de casos confirmados mundialmente. Cf. WORLD HEALTH ORGANIZATION (2019).

${ }^{13}$ Boatos sobre a origem, o alcance, bem como métodos alternativos de prevenção contra a covid-19 surgiram em larga escala logo nas primeiras semanas da pandemia do novo coronavírus, cf. BBC Monitoring e UGC Newsgathering (2020).

${ }^{14}$ Sobre o tema, para maior desenvolvimento, v., por todos, Sarlet e Ferreira Neto (2018).
} 
em torno de um sufrágio consciente e informado), a isonomia do e no processo eleitoral (incluindo a igualdade de oportunidades) e o próprio princípio e regime democrático, ademais do efetivo e adequado funcionamento de suas instituições. Tudo isso será ainda objeto de atenção nos desenvolvimentos seguintes.

\subsection{LIBERDADE DE EXPRESSÃO E DE INFORMAÇÃO, REDES SOCIAIS E DEMOCRACIA: UMA APROXIMAÇÃO}

Elemento essencial de uma ordem democrática e corolário da tradição liberalindividualista que radica na base do moderno constitucionalismo, a liberdade de expressão nunca deixou de ser ameaçada e violada, carecendo de particular proteção, exigência que se agudiza em termos quantitativos e qualitativos no âmbito digital. Por outro lado, como já antecipado, também o uso abusivo da liberdade de expressão, muitas vezes já resultou na fragilização e mesmo desconstrução da Democracia e de democracias, o que também restou potencializado na era digital e os recursos cada vez mais sofisticados das tecnologias de comunicação e informação.

Na perspectiva do Direito, um dos principais desafios segue sendo o de buscar assegurar um equilíbrio entre o exercício pleno da liberdade de expressão e de informação nas suas mais diversas dimensões, por um lado, e a necessária proteção da dignidade da pessoa humana, dos direitos de personalidade, por outro, mas, também, o de operar como instrumento para a afirmação, do pondo de vista transindividual, de um ambiente com níveis satisfatórios de proteção desses direitos, o que, por sua vez, implica a salvaguarda dos direitos políticos e da democracia e suas instituições. Nesse sentido, convém sempre relembrar a emblemática assertiva de HÄBERLE, de que a dignidade humana é a premissa, fundamento e princípio estruturante de uma democracia, ao passo que a democracia opera como espécie de garantia organizacional e procedimental da dignidade humana (2009, p. 86 e ss).

Da mesma forma segue atual a lição de MICHELMAN, quando sublinha que a relação entre democracia e liberdade de expressão é de um recíproco condicionamento e assume um caráter complementar, dialético e dinâmico, de modo que, embora mais democracia possa muitas vezes significar mais liberdade de expressão e vice-versa (mais liberdade de expressão indica mais democracia), também é correto que a liberdade de expressão pode acarretar riscos para a democracia o que, por sua vez, pode comprometer a liberdade de expressão (2007, p. 58).

Daí porque sem a manutenção de um equilíbrio, que ao mesmo tempo garanta o máximo em liberdade de expressão e assegure a proteção da dignidade da pessoa humana e do livre desenvolvimento da personalidade em todas as suas dimensões, o próprio Estado Democrático de Direito, necessariamente livre, plural e igualitário, estará em risco. 
É nesse contexto, portanto, que se situa o problema do uso de redes sociais online, pelo fato de que por seu intermédio se viabiliza massivamente um fluxo informacional que coloca em contato e mantém conectado cada vez mais indivíduos e grupos (pessoas naturais e jurídicas), mas também governos e outros atores.

Por essa razão é importante assentar o que se compreende por redes sociais, de modo que se atenta à definição por Boyd e Ellison, porquanto tais redes consistem em meios - embora variem em seus contornos de website para website - de articular e manejar um perfil a partir do qual seja possível estabelecer conexões com outros que compartilham o mesmo sistema (BOYD; ELISSON, 2008, p. 211). Em que pese tal conceito empregado pelas autoras seja pertinente, o que se compreende por redes sociais a isso não mais se limita.

Há dois pontos a serem destacados, que não foram desenvolvidos pelas autoras acima referidas. $\mathrm{O}$ primeiro diz respeito ao fato de uma rede social permitir a autoexpressão do indivíduo, uma vez que essa nem sempre ocorre por meio de uma conexão direta com outras pessoas, como se pode verificar invocando o exemplo da rede social Twitter, caracterizada por permitir postagens curtas e nem sempre com a interação dos demais usuários, mediante curtidas, retweets e respostas.

O segundo ponto concerne ao manejo de um perfil, porquanto nem sempre estaremos com a representação de um perfil pessoal online, ainda que as pessoas, com base em si mesmas, elaboram um alter ego (persona) digital. O manejo de perfis como delimitador do que seja uma rede social não se sustenta na medida em que há o desenvolvimento dos recursos de conversação privada, que não permitem uma interação pública do usuário. Tais interações podem se dar tanto de maneira peer-to-peer (entre duas pessoas apenas), como em grupos (entre três pessoas ou mais).

À vista do exposto, está demonstrada a possibilidade de existirem redes sociais em grupos de aplicativos e sites privados para conversação em grupo, a fim de que efetivamente exista uma Rede nos termos cunhados por Manuel Castells (CASTELLS, 2005).

Em caráter complementar, invoca-se o conceito adotada pelo Tribunal Superior Eleitoral brasileiro, na Resolução 23.551/1917, quando define redes sociais como sendo "estrutura[s] socia[is] composta[s] por pessoas ou organizações, conectadas por um ou vários tipos de relações, que compartilham valores e objetivos comuns" (BRASIL. Tribunal Superior Eleitoral, 2017b).

As redes sociais online, assim, dada a sua configuração e abertura, ademais de seu alcance global, passaram a ocupar uma posição de destaque no que se entende por esfera pública de uma sociedade em rede, assumindo até mesmo a função de uma espécie de ágora digital (CASTELLS, 2005; PÉREZ LUÑO, 2014, p. 10).

No entanto, ainda que seja mediante a (re)união de pessoas que "o exercício coletivo da liberdade de expressão e manifestação do pensamento po[ssa] servir 
como instrumento eficiente para a luta política e assegurar a possibilidade de influenciar o processo político" (SARLET; WEINGARTNER NETO, 2014, p. 480), o cenário traçado pelas redes sociais quando se trata de desinformação, de certo modo coloca em xeque tanto a liberdade de expressão como a liberdade de informação.

Isso se dá pelo fato de que o recurso às fake news e às diversas formas de desinformação compromete o pleno (aqui não no sentido de ideal) exercício da liberdade de expressão, porquanto para tanto as informações nas quais as pessoas se amparam para manifestar opiniões devem ser confiáveis, documentadas, ou, pelo menos, passíveis de serem reconduzidas a fontes apropriadas, de modo a não se configurar um reinado da "sabedoria das multidões" (KAKUTANI, 2018, p. 12), com o que não se está evidentemente a dizer que é possível (e mesmo desejável) interditar todo e qualquer tipo de discurso "irracional", sentimental e mesmo contra fático, visto inexistir um direito (e respectivo dever) à verdades "absolutas" ou discursos ancorados em dados científica e ou historicamente comprovados e documentados.

Ainda nesse contexto, cabe frisar que as redes sociais que não efetuam filtragem prévia de conteúdo e nem exercem algum tipo de controle editorial (ALLCOTT; GENTZKOW, 2017, p. 211) tornaram-se, em maior ou menor medida, bolhas de interesse compartilhado, visto que fornecem - em função do algoritmo que organiza o feed das redes - informações que tendem a confirmar a visão de mundo do usuário $^{15}$ (KAKUTANI, 2018, p. 144; ALLCOTT; GENTZKOW, 2017, p. 221; SUNSTEIN, 2010, p. 56). Tendo em vista que nem toda pessoa receberá as mesmas informações no seu feed (TUFEKCI, 2015, p. 205), verificando-se uma limitação da liberdade de informação desses usuários ${ }^{16}$. No mesmo sentido situa-se o assim designado "banimento fantasma" (do inglês, ghost banning), que igualmente impacta a liberdade de expressão e de informação, porquanto nesses casos o conteúdo postado na rede social acaba por ser ignorado pelo algoritmo que não viabiliza a visualização do conteúdo publicado por outros usuários (EPISTOCRACIA, 2018).

\footnotetext{
${ }^{15}$ Em razão disso, algumas redes sociais - incluindo o Facebook - realizaram uma atualização do seu algoritmo, para manter o que é do interesse do usuário no seu feed, ao mesmo tempo que remove, ou, pelo menos, fornece menos visualização às notícias falsas. No entanto, tal atualização do Facebook não obteve os resultados esperados, v. FACEBOOK'S fake (2018).

${ }^{16}$ Relembra-se também, de outra atualização de algoritmos; desta vez, do Google, em 2016. Aliás, o Google não apenas realizou uma nova atualização do seu algoritmo, para literalmente retirar (i.e., desindexar) do seu mecanismo de busca determinados resultados que poderiam, de acordo com o algoritmo, criar uma esfera falaciosa acerca de algo ou alguém, como também instituiu a ferramenta do Fact-checking (GINGRAS, 2016), a qual, por sua vez, por meio da tag verificação de fatos, próxima ao título, destaca as informações falsas ou verdadeiras nos resultados de pesquisa do Google e no Google Notícias, as quais foram checadas pelas mais de cem agências de verificação de fatos, dentre elas a The International Fact-Checking Network, sediada no Poynter Institute (no Brasil, destacam-se as agências Lupa, Aos Fatos e Agência Pública).
} 
Que os fenômenos relatados, que não constituem um numerus clausus, impactam também o processo político-eleitoral já soa como algo elementar, mas será objeto de maior desenvolvimento mais adiante, pois antes imprescindível apresentar, em breves traços, o marco jurídico-constitucional que baliza a discussão em torno do conteúdo e dos limites das liberdades de expressão e de informação, a partir do qual se poderá analisar se e em que medida o recurso às fake news poderá, ou não, ser regulado, proscrito ou então restringido nas eleições.

\subsection{A POSIÇÃO PREFERENCIAL DA LIBERDADE DE EXPRESSÃO E DE INFORMAÇÃO NA ARQUITETURA CONSTITUCIONAL BRASILEIRA E SEU SIGNIFICADO}

Como amplamente conhecido, o problema do conteúdo e limites da liberdade de expressão somente pode ser enfrentado e equacionado, do ponto de vista jurídico, quando existe um consenso (no sentido de uma opinião e prática majoritária) relativamente ao seu sentido e alcance numa determinada ordem constitucional, o que, por sua vez, remete à querela em torno da posição da liberdade de expressão em relação aos demais direitos fundamentais. Note-se, ainda, que a importância da discussão em torno do peso relacional da liberdade de expressão para o presente texto, é que ela impacta diretamente o modo de enfrentamento dos problemas relativos à disseminação de fake news e de sua eventual interdição.

Nesse contexto, mediante um primeiro olhar sobre o texto constitucional, designadamente dos preceitos sobre a liberdade de expressão e os direitos de personalidade, a impressão que se tem, com base no teor literal dos respectivos preceitos, é que a Constituição (doravante $\mathrm{CF}$ ) atribui idêntico valor tanto à proteção à intimidade, privacidade, honra e imagem, quanto à liberdade de manifestação de pensamento e de expressão artística, intelectual, científica e de comunicação ${ }^{17}$.

Todavia, mesmo que, em um primeiro momento, a CF assegure um idêntico status protetivo à privacidade, intimidade, honra e imagem e à liberdade de manifestação e expressão, percebe-se que, em relação à segunda, o texto constitucional entendeu por bem ser mais explícito e detalhista no que se refere aos critérios de controle e de restrição dessa liberdade, tal como se vê das regras constitucionais contidas nos arts. 220 e 221. Isso porque a CF, além de fixar de antemão impedimentos legislativos ( $\S 1^{\circ}$ e $\S 3^{\circ}$ do art. 220), entendeu por bem já prever a proibição categórica à censura ( $\S 2^{\mathrm{o}}$ do art. 220), assim como fixar princípios diretivos que deverão guiar a produção publicitária, de rádio e de televisão (§§ $4^{\circ}, 5^{\circ}$ e $6^{\circ}$ do art. 220 e art. 221).

\footnotetext{
17 “Art. 5o (...) IV - é livre a manifestação do pensamento, sendo vedado o anonimato; IX - é livre a expressão da atividade intelectual, artística, científica e de comunicação, independentemente de censura ou licença; $X$ - são invioláveis a intimidade, a vida privada, a honra e a imagem das pessoas, assegurado o direito a indenização pelo dano material ou moral decorrente de sua violação".
} 
Tal opção constitucional pode ser interpretada como sendo um sinal de que o Constituinte foi mais seletivo no que se refere às restrições que poderão ser aplicadas à liberdade de imprensa, de manifestação de pensamento e de expressão do que foi em relação à proteção da intimidade e da privacidade, a qual deverá contar com uma ponderação a posteriori para identificar as situações de grave e intolerável interferência na esfera de proteção privada. Ou seja, os limites (e consequentes restrições) de tais liberdades já estão, em grande parte, pré-fixadas na $\mathrm{CF}$, ao passo que eventuais restrições aos direitos de personalidade foram deixadas para especificação posterior, não só pelo legislador, como pela apreciação equitativa do Judiciário. Essa opção do Constituinte de 1988 pode ser interpretada como indicando a escolha constitucional por tratar restrições à liberdade de manifestação e expressão como sendo algo excepcional, exigindo que eventuais restrições adicionais necessitem de um esforço argumentativo diferenciado e mais intenso que consiga justificar a necessidade particular de uma nova limitação.

É nessa perspectiva que se pode afirmar que, mediante uma interpretação sistemática - aliada ainda ao fato de ser a liberdade de expressão e informação indispensável (e mesmo estruturante) a um regime democrático - a CF assegurou a tais liberdades uma posição (relativa) preferencial em face dos direitos de personalidade, que pode ser compreendida como uma preferência prima facie. Aliás, esse tem sido - ao menos até o momento - o entendimento que tem prevalecido na literatura nacional (embora a existência de significativo dissenso) ${ }^{18}$ e na jurisprudência, em especial nos Tribunais Superiores, com destaque aqui para o STF, ao menos em se levando em conta os principais casos julgados nos últimos anos, tem apontado para uma posição preferencial da liberdade de expressão e informação.

Dentre os casos julgados pelo STF envolvendo a liberdade de expressão e indicando sua posição preferencial, podem ser colacionados a declaração da não recepção, por incompatibilidade com a CF, da antiga Lei de Imprensa elaborada no curso do regime militar, quando o relator, Ministro Carlos Britto, afirmou que a liberdade de expressão assume uma posição quase absoluta e apenas pode ser objeto de limitação nos casos expressamente estabelecidos pela própria constituição originária, designadamente o direito à indenização e o direito de resposta (BRASIL, 2009). Da mesma forma chamam a atenção dois outros casos, o assim chamado caso "marcha da maconha", no qual o STF entendeu que uma manifestação pública e coletiva em prol da legalização do consumo da maconha não poderia ser enquadrada no tipo penal da apologia ao crime (BRASIL, 2011). Também merecem referência, entre outros, os casos das biografias não autorizadas, no qual o STF decidiu ser inconstitucional a exigência de prévia autorização do biografado (BRASIL, 2015), bem como o julgado que traçou uma diferenciação, no que diz com o processo eleitoral, entre críticas veiculadas mediante sátiras e charges e

${ }^{18}$ Em caráter ilustrativo destacam-se aqui, em favor da posição preferencial, Barroso (2005, p. 103), bem como, mais recentemente, Sarmento (2018). 
manifestações de humor em geral e as assim chamadas fake news, liberando as primeiras (BRASIL, 2018).

À vista do exposto é possível, à guisa de conclusão parcial, assumir como correto (pelo menos fortemente sustentável do ponto de vista jurídicoconstitucional), as seguintes premissas: $(i)$ as liberdade de expressão e de informação ocupam uma posição preferencial relativa na arquitetura constitucional brasileira; (ii) eventuais restrições à liberdade de expressão, como também se extrai dos julgados acima colacionados, não são ilegítimas, mas carecem de robusta justificação e reforçado ônus argumentativo.

\section{FAKE NEWS NAS REDES SOCIAIS ONLINE, ELEIÇÕES E SEU IMPACTO SOBRE A DEMOCRACIA NO BRASIL}

Como já adiantado, o recurso às diversas formas de desinformação, em especial das assim chamadas fake news, em processos eleitorais tem crescido exponencialmente nos últimos anos, o que, por sua vez, guarda relação direta com a expansão das redes sociais em termos de número de usuários e dos recursos que lhes são colocados à disposição para a postagem e compartilhamento dos conteúdos mais diversos, de modo a ser imprescindível tratar do fenômeno em sua conexão com a democracia.

\subsection{NOTAS SOBRE O ACESSO ÀS REDES SOCIAIS NA INTERNET E SUA UTILIZAÇÃO NO PROCESSO ELEITORAL}

Tendo em conta o objeto do presente estudo, que analisa a realidade brasileira, antes de avançar com as questões ligadas diretamente às fake news, é o caso de demonstrar, mediante alguns dados, como se dá o acesso às redes sociais no Brasil, em especial o número de usuários, e, à luz do exemplo das eleições gerais de 2018, em que nível as redes sociais foram utilizadas no embate eleitoral, destaque para as eleições presidenciais.

No que tange ao engajamento dos brasileiros nas redes sociais em sentido amplo, não se restringindo ao período eleitoral, de acordo com pesquisa publicada pela Global Web Index (Q3 2019), o Brasil é o terceiro país do Mundo cujos usuários - entre 16 e 64 anos de idade - passam mais tempo em redes sociais, independentemente de qual o dispositivo e plataforma utilizados, atrás apenas das Filipinas e da Colômbia, de acordo com pesquisa publicada em janeiro de 2020 (GLOBAL WEB INDEX, 2020).

Ademais disso, dentre as principais redes sociais utilizadas no Brasil, segundo plataforma de análise de dados Statistica, o WhatsApp é a rede social mais utilizada entre os brasileiros (66\% dos entrevistados), cabendo agregar que não se trata de um mero mecanismo de conversação privada, uma vez que permite a ampla formação de grupos específicos e compartilhamento de informações entre si. $\mathrm{Na}$ sequência, aparecem as redes sociais Facebook (59\% dos entrevistados), YouTube 
( $37 \%$ dos entrevistados) e o Instagram ( $27 \%$ dos entrevistados) ${ }^{19}$. Ainda no que tange ao número de usuários no país comparado à população total brasileira, de acordo com pesquisa publicada em janeiro de 2020, sem parâmetros específicos para idade dos indivíduos, $66 \%$ são membros ativos das redes sociais.

Tais dados, inclusive, guardam sintonia com os divulgados para as eleições de 2018, segundo o Instituto Data Folha, de acordo com os quais, "dois em cada três eleitores brasileiros (66\%) têm contas em redes sociais" (INSTITUTO DATAFOLHA, 2018, p. 37), atingindo considerada relevância o reconhecimento pela Organização dos Estados Americanos de que, em 2018, o "uso de fake news nas eleições do Brasil [foi] 'sem precedentes'" (OEA diz, 2018), cujo foco principal de disseminação de notícias falsas se deu em âmbito online.

Segundo o Instituto Data Folha, em pesquisa realizada durante o ano eleitoral (2018) 41\% dos entrevistados que afirmaram ter conta no WhatsApp, disseram acreditar um pouco em notícias recebidas pelo aplicativo, enquanto $6 \%$ acreditam muito. Ainda assim, há uma inversão da opinião dos entrevistados no que tange à população brasileira como um todo, uma vez que $62 \%$ dos entrevistados afirmaram que os brasileiros, em sentido amplo, acreditam muito nessas notícias, ao passo que apenas $25 \%$ dos entrevistados afirmaram que os brasileiros, em sentido amplo, acreditam um pouco nas informações recebidas por meio do aplicativo. Apenas 8\% dos entrevistados afirmaram que os brasileiros, em sentido amplo, não acreditam, ao passo que 53\% dos entrevistados, agora em perspectiva individual, assumem não acreditar nessas notícias (INSTITUTO DATAFOLHA, 2018, p. 11).

A partir desses dados, é possível inferir que muitos brasileiros creem que a população geral acredita nas "notícias de WhatsApp", mas eles próprios, quando perguntados, demonstram-se céticos quanto a essas informações, corroborando com a política do "nós e eles", isto é, "eu, sou bem informado(a) e não acredito em fake news, mas os brasileiros acreditam".

Aliás, de acordo com a pesquisa do mesmo Instituto, quanto mais se avança na faixa de idade na pesquisa realizada, maior o engajamento dos seus usuários no compartilhamento de mensagens com conteúdo político. Os mais jovens tendem a não compartilhar mensagens sobre eleições e política quando comparados aos mais velhos. Ainda que os entrevistados na faixa de idade dos 16 a 24 anos sejam o grupo com mais contas no WhatsApp, apenas $29 \%$ utilizam tal canal de comunicação para compartilhar notícias sobre eleições ou política. Na faixa dos 35 aos 44 anos, dos $73 \%$ que utilizam o aplicativo, 39\% desses o fazem também para o efeito de compartilhar conteúdos de natureza político-eleitoral. No caso dos entrevistados entre 45 e 59 anos, dos 54\% que têm conta no WhatsApp, 44\% desses repassam mensagens de natureza política, ao passo que, na última faixa, mais de 60 anos de idade, $33 \%$ têm conta no aplicativo, dos quais $44 \%$ o utilizam para

\footnotetext{
${ }^{19}$ A pesquisa se realizou durante os dias 15 de junho e 15 de julho de 2018, sendo apresentada em novembro do mesmo ano. A pesquisa contou com 1.204 respondentes, os quais tinham, à época, 16 anos ou mais. Cf. Statistica (2018).
} 
compartilhamento de conteúdo político (INSTITUTO DATAFOLHA, 2018, p. 2 e 33).

Uma vez traçado esse panorama, a problemática das fake newss se agrava na medida em que, de acordo com estudo da Universidade de Regina, no Canadá, realizado nos Estados Unidos com 2.500 participantes (PENNYCOOK; EPSTEIN; MOSLEH; ARECHAR; ECKLES; RAND, 2019), as pessoas divulgam fake news de modo consciente, com o intuito de confirmar suas convicções pessoais, ainda que, quando perguntados diretamente, a maioria dos participantes da pesquisa tenham sustentado a importância de compartilhar-se apenas informações fidedignas. Assim, caso um usuário encontre uma informação que confirme suas opiniões próprias, em que pese não advenha de fonte segura, há mais chances de tal informação ser compartilhada com outras pessoas.

Feitas tais constatações, analisa-se o panorama legislativo para a proteção do debate democrático-eleitoral no Brasil, tendo in mente a importância de um debate polido, livre de boatos e para uma plena democracia.

\subsection{O MARCO JURÍDICO-CONSTITUCIONAL VIGENTE E A REGULAÇÃO DO RECURSO ÀS FAKE NEWS NAS REDES SOCIAIS}

Embora a CF contenha dispositivos voltados ao processo eleitoral, ademais de um conjunto de princípios, direitos e deveres não focados aos direitos políticos, partidos políticos e eleições, mas de alta relevância para a sua intepretação/aplicação, como é o caso das liberdades comunicativas (expressão e de informação, artística, reunião e manifestação, igualdade na dimensão formal e material, direitos e garantias em matéria processual, penal, dentre tantos outros), é no plano da legislação infraconstitucional e mesmo, em especial no caso das eleições, infralegal, que se dá a regulação mais detida dos mais diversos aspectos vinculados ao processo eleitoral.

Com isso, é claro, não se está a desconsiderar a esfera constitucional, que segue sendo o ponto de partida e o parâmetro da legitimidade jurídica do marco regulatório infraconstitucional, o que pode ser ilustrado mediante o exemplo da liberdade de expressão e de informação e sua posição preferencial na ordem jurídica brasileira, mas também pelos direitos de personalidade que eventualmente lhe podem ser impostos, ademais da necessidade de a normativa ordinária (legal e infralegal) observar as exigências postas expressa e implicitamente pela $\mathrm{CF}$ nos casos de restrição de tais direitos fundamentais.

Outrossim, levando em conta que o recurso ao marco normativo constitucional se dará mais adiante, quando da análise mais detida e crítica do estado da arte (destaque para a seara normativa e jurisprudencial) regulatório aplicável e aplicado às fake news em matéria eleitoral, inicia-se com um inventário da legislação e demais atos de caráter normativo em vigor, bem como da jurisprudência do STF e do TSE na matéria. 
Trata-se, como é notório, de uma tarefa nada simples, seja em virtude da dinamicidade e casuísmo que, em larga medida, caracteriza a produção normativa em matéria eleitoral, que não se resume a um diploma à feição de uma codificação, apesar da existência de um Código Eleitoral (Lei n. 4.737/1965), que, contudo, em especial em virtude do disposto no art. 16 da $C F$, foi em parte revogado (e substituído) mediante a edição de uma - à época - nova lei, a assim chamada Lei das Eleições (Lei n. 9.504/97).

Importa ressaltar, portanto, as alterações trazidas pela Lei n. 13.877/2019 e pela Lei n. 13.878/2019, e no que tange ao presente estudo, a permissão da primeira quanto ao impulsionamento eletrônico nas redes sociais, a partir da contratação direta com o provedor de aplicações (inserção do inciso XI ao art. 44 da Lei dos Partidos Políticos (Lei n. 9.096/1995) ${ }^{20}$, já viabilizada para ocorrer durante as eleições municipais previstas para o ano de 2020, razão pela qual também faz-se referência à Resolução n. 23.610/2019 do TSE, que dispõe, no que aqui importa, sobre a propaganda eleitoral e condutas ilícitas em campanha eleitoral ${ }^{21}$.

Tal normativa, importa sublinhar, dialoga com os instrumentos para remoção de conteúdos e outros cabíveis, previstos na Lei n 12.965/2014 (doravante Marco Civil da internet), largamente utilizado para retirada de fake news nas redes sociais, inclusive em períodos eleitorais, como, aliás, será mais desenvolvido na sequência.

Iniciando-se com o Código Eleitoral, este contempla alguns dispositivos que podem ser aplicados, em maior ou menor medida e a depender das circunstâncias, ao combate das fake news, inclusive na esfera criminal.

Nesse contexto, sobressai-se o art. 323, que criminaliza a conduta de "divulgar, na propaganda, fatos que sabe inverídicos, em relação a partidos ou candidatos e capazes de exercerem influência perante o eleitorado", cuja pena de detenção ou pagamento de multa é agravada caso o delito seja perpetrado através imprensa, rádio ou televisão. Tal dispositivo consiste em "uma figura autônoma do Direito Eleitoral, que não encontra similar exato na legislação penal comum, ao contrário das subsequentes figuras da calúnia, injúria e difamação" (GONÇ̧ALVES, 2015, p. 80), que serão analisadas logo adiante.

Aliás, importa sublinhar que os delitos crimes contra honra não se confundem com o tipo penal acima referido, uma vez que basta o falso conteúdo divulgado incidir sobre o pleito eleitoral (GONÇ,ALVES, 2015, p. 81). Todavia, há quem

\footnotetext{
20 "Art. 44. Os recursos oriundos do Fundo Partidário serão aplicados: XI - no custeio de impulsionamento, para conteúdos contratados diretamente com provedor de aplicação de internet com sede e foro no País, incluída a priorização paga de conteúdos resultantes de aplicações de busca na internet, mediante o pagamento por meio de boleto bancário, de depósito identificado ou de transferência eletrônica diretamente para conta do provedor, o qual deve manter conta bancária específica para receber recursos dessa natureza, proibido nos 180 (cento e oitenta) dias anteriores à eleição" (grifou-se).

${ }^{21}$ Refere-se que a presente pesquisa, o próximo período eleitoral e a resolução citada possam ser afetados, em maior ou menor grau, pelas consequências geradas a partir da pandemia da covid19.
} 
critique a formulação adotada pelo Código Eleitoral, dada a falta de congruência no que diz com a agravante de pena, porquanto esta não considera a divulgação de falsidades na internet, o que, no entanto, não havia como ser previsto pelo legislador de 1965 e demanda uma alteração legislativa (GONÇ_ALVES, 2015, p. 82). Além disso, exige-se que não apenas aquele que divulga o(s) fato(s) deverá ter ciência de tal falsidade (GONÇ,ALVES, 2015, p. 80), como também ela deve ser veiculada "na propaganda eleitoral" (BRITO; LONGHI, 2014, p. 103), seja ela partidária, intrapartidária ou eleitoral stricto sensu (GONÇ,ALVES, 2015, p. 80).

Com efeito, tendo como base o art. 57-J da Lei das Eleições ${ }^{22}$ (cujo caráter aberto é de ser melhor discutido noutro momento ${ }^{23}$, o Tribunal Superior Eleitoral, na referida Resolução (art. 27, § $6^{\circ}$ ), determinou que manifestações de indivíduos em redes sociais em favor de determinado partido ou candidato não configuram propaganda eleitoral ${ }^{24}$. Portanto, manifestações de indivíduos em redes sociais estão fora do escopo do crime previsto no art. 323, do Código Eleitoral, que criminaliza a divulgação, em propaganda eleitoral, de fatos inverídicos, uma vez que tais manifestações de acordo com o TSE, não constituem tal prática.

Em que pese tal apontamento, os indivíduos que incorrerem em tal prática permanecem submetidos às penalidades previstas na legislação, a depender das características especiais de cada fato. Nessa linha, caso a informação veiculada inclusive a falsa - venha a ofender a honra subjetiva ou objetiva de candidatos, ainda na propaganda, recai-se nos tipos penais previstos no art. 324, no art. 325 e no art. 326 do Código Eleitoral (respectivamente, calúnia, difamação e injúria eleitorais), não se aplicando, nesses casos, os crimes contra a honra previstos no Código Penal. Aliás, a elevação da honra a bem jurídico-penal é criticada, uma vez que tais conflitos poderiam ser facilmente resolvidos na esfera extra penal, o que não é aqui o nosso objeto de análise. No entanto, mantém-se tal configuração penal, cuja inserção foi fundamentada pelo "elevado número de conflitos derivados da violação à honra até o fim do século XIX. Afrontas e desaforos desaguavam, não

\footnotetext{
22 “Art. 57-J. O Tribunal Superior Eleitoral regulamentará o disposto nos arts. 57-A a 57-I desta Lei de acordo com o cenário e as ferramentas tecnológicas existentes em cada momento eleitoral e promoverá, para os veículos, partidos e demais entidades interessadas, a formulação e a ampla divulgação de regras de boas práticas relativas a campanhas eleitorais na internet".

${ }^{23}$ Ainda que melhores e maiores aprofundamentos sejam mais adequados em momento oportuno, em síntese, cabe aqui referir que, no que tange ao fenômeno da desinformação no período eleitoral de 2020, a Resolução aponta que, nas propagandas eleitorais, há a presunção de que o candidato, partido ou coligação tenham verificado a veracidade das informações de todos os conteúdos ali presentes, incluindo aqueles veiculados por terceiros, restando os responsáveis, em caso de divulgação de material inverídico, sujeitos ao capítulo da Lei das Eleições referente ao direito de resposta (art. 9o da Resolução).

${ }^{24}$ Vale ressaltar que o mesmo foi determinado durante as eleições de 2018, vide. art. 23, § $6^{0}$ da já superada Resolução 23.551/2017, do TSE.
} 
raro, em rixas e duelos, justificando a repressão de cunho criminal" (SCHREIBER, 2013, p. 72).

Com efeito, trazem-se à baila os tipos penais previstos no $\S 1^{\circ}$ e $\S 2^{\circ}$ do art. $57-H$, da Lei das Eleições, nos quais determina-se que "constitui crime a contratação direta ou indireta de grupo de pessoas com a finalidade específica de emitir mensagens ou comentários na internet para ofender a honra ou denegrir a imagem de candidato, partido ou coligação" ( $\$ 1^{\circ}$ do art. 57-H), incorrendo também em pena, mesmo que menos gravosa, aquele que foi contratado para tanto ( $\$ 2{ }^{\circ}$ do art. $\left.57-\mathrm{H}\right)$.

Logo, caso um grupo tenha sido contratado para proferir difamações (fato inverídico desabonador) ou calúnias (falsa imputação de crime) sobre candidato, partido ou coligação capazes de influir no pleito, há a incidência desse dispositivo. Em face disso, ainda que em tais delitos veja-se a honra como o bem jurídico protegido, estes devem repercutir no contexto eleitoral afetando a lisura do pleito. No entanto, caso o candidato seja ofendido fora da propaganda eleitoral, ou sem fins de propaganda, recair-se-á nos tipos previstos no Código Penal (GONCşALVES, 2015, p. 83).

Além disso, o "ofendido por calúnia, difamação ou injúria, sem prejuízo e independentemente da ação penal competente, poderá demandar, no Juízo Civil a reparação do dano moral respondendo por este o ofensor e, solidariamente, o partido político deste, quando responsável por ação ou omissão a quem que favorecido pelo crime, haja de qualquer modo contribuído para ele" ( $\$ 1^{\circ}$ do art. 243 do Código Eleitoral).

Dando continuidade à apreciação, demonstra-se que os principais dispositivos eleitorais que regem o comportamento nas redes sociais online estão contidos na Lei das Eleições. Por isso, desloca-se o foco para o disposto no art. 33 , $\S 4^{\circ}$, daquele diploma legal, pelo qual "a divulgação de pesquisa fraudulenta constitui crime, punível com detenção de seis meses a um ano e multa no valor de cinquenta mil a cem mil UFIR". Dito de outro modo, classificou-se como conduta reprovável em período eleitoral a divulgação de pesquisa eleitoral fraudulenta, porquanto reconhecida a possibilidade de pesquisas eleitorais (des)orientarem determinada escolha de voto, bem como impactar negativamente a reorganização da campanha eleitoral de determinado partido ou candidato, além de ascender debates entre o eleitorado (GONC,ALVES, 2015, p. 128).

Em sentido técnico, pesquisas eleitorais possuem o escopo de "demonstrar a tendência eleitoral da população, funcionando como fator de avaliação da campanha e de correção nos rumos da disputa política" (AGRA; CAVALCANTI, 2010, p. 50). Para agravar a situação, vale referir pesquisa realizada pela Universidade Columbia, New York, e o Instituto Nacional francês de Pesquisa em Informática e Automação, segundo a qual 59\% dos links compartilhados nas mídias sociais não são abertos por quem os compartilha (BALEM, 2017, p. 4), podendo induzir em erro o voto de determinado indivíduo, ou, no caso da internet, de diversos eleitores (GONC,sLVES, 2015, p. 128). 
Vale dizer, nessa senda, que a internet é um dos meios mais eficazes - se não o mais eficaz - para a elaboração de campanha eleitoral (art. 57-A da Lei das Eleições), até porque é permitida inclusive durante o interstício, que compreende as 48 horas anteriores até as 24 horas posteriores à eleição. Ainda assim, não é possível fazer campanha sem qualquer entrave. No que toca à propaganda eleitoral na internet, os $\S \S 1^{0}$ e $2^{\circ}$ do art. 57-A da Lei das Eleições estabelecem que "a livre manifestação do pensamento do eleitor identificado ou identificável na internet somente é passível de limitação quando ocorrer ofensa à honra de terceiros ou divulgação de fatos sabidamente inverídicos" ( $\left(1^{\circ}\right)$, aplicando tal disposição "inclusive, às manifestações ocorridas antes da data prevista [para o início de campanha eleitoral na internet], ainda que delas conste mensagem de apoio ou crítica a partido político ou a candidato, próprias do debate político e democrático".

Quanto ao impulsionamento de conteúdos a legislação eleitoral carece de técnica legislativa adequada. Para a Lei das Eleições, a utilização de ferramentas digitais é permitida, "desde que não contrate impulsionamento de conteúdos" (art. 57-B, inciso IV, alíneas "a" e " $b$ " da Lei das Eleições), cujo conceito abrange também a "priorização paga de conteúdos resultantes de aplicações de busca na internet" ( $2^{2}$ o do art. 26 da Lei das Eleições $)^{25}$. Já a teor do $§ 3^{\circ}$ do art. 57-B da Lei das Eleições, "é vedada a utilização de impulsionamento de conteúdos e ferramentas digitais não disponibilizadas pelo provedor da aplicação de internet, ainda que gratuitas, para alterar o teor ou a repercussão de propaganda eleitoral, tanto próprios quanto de terceiros".

No entanto, tal norma regulamentadora precisa ser lida de forma sistemática, uma vez que o inciso XI do art. 44, da Lei dos Partidos Políticos (Lei no 9.096/1995), permite a aplicação de recursos do Fundo Partidário ao custeio de impulsionamento de conteúdo na internet, desde que contratado diretamente com o provedor limitando-se aos por esse disponibilizados. Em outras palavras, o impulsionamento é permitido desde que a sua contratação não seja delegada a terceiros.

Ainda nessa linha, no que respeita ao usa da tecnologia para promoção de candidatos e partidos em períodos eleitorais, calha destacar que nas últimas eleições brasileiras, em 2018, foi identificado um aglomerado de perfis falsos os quais tinham como objetivo influenciar a votação (INSIDE, 2018). Embora não se trate de um impulsionamento de conteúdo per se, o uso de bots (cyborgues)

\footnotetext{
${ }^{25}$ Ainda assim, importante destacar, uma vez que lastreada na prerrogativa do TSE de moldar as normas para o cenário eleitoral à tecnologia desenvolvida até o momento da realização do pleito, que a Resolução para as eleições de 2020 caracteriza impulsionamento como sendo aquele "o mecanismo ou serviço que, mediante contratação com os provedores de aplicação de internet, potencializem o alcance e a divulgação da informação para atingir usuários que, normalmente, não teriam acesso ao seu conteúdo, incluída entre as formas de impulsionamento a priorização paga de conteúdos resultantes de aplicações de busca na internet" (inciso XIV, art. 37, da Resolução).
} 
(GABINETE, 2020), consiste num uso indevido da rede, mediante a contratação de terceiros, para fomentar determinado candidato, de modo que "entre 9 e 15\% de contas ativas do Twitter são bots. O Facebook, aliás, estimou que em média 60 milhões de bots podem estar infestando a plataforma" (Traduziu-se. LAZER; BAUM; BENKLER, 2018, p. 1095), criando uma esfera falaciosa de apoio a determinado candidato. Ainda que os cyborgues não criem desinformação de modo preciso, eles são eficientes na sua publicação e compartilhamento (Traduziu-se. WARDLE, 2017, p. 39), razão pela qual "não é admitida a veiculação de conteúdos de cunho eleitoral mediante cadastro de usuário de aplicação de internet com a intenção de falsear identidade" (art. 57-B da Lei das Eleições), "atribuindo indevidamente sua autoria a terceiro, inclusive a candidato, partido ou coligação" (art. 57-H da Lei das Eleições).

Nesse passo, destaca-se o art. 57-I da Lei das Eleições que permite, a requerimento de candidatos, partidos políticos ou coligações, a suspensão de conteúdo que divulgue informações inverídicas nas redes sociais, sendo que o número de horas de suspensão é definido de forma proporcional de acordo com o caso concreto, não ultrapassando o total de vinte e quarto horas. Ainda que a lei utilize a terminologia suspensão, que implica em ser algo temporário, o que efetivamente ocorre é remoção do conteúdo, sem que ele retorne a aparecer novamente, sendo, portanto, permanente.

Aliás, a Resolução para as eleições de 2020 não esclareceu os pontos obscuros da redação da legislação eleitoral, tendo apenas determinado que a "remoção" deva se dar em prazo "não inferior a 24 (vinte e quatro) horas, e deverá conter, sob pena de nulidade, a URL e, caso inexistente esta, a URI ou a URN do conteúdo específico", além de apontar que, depois do término do período eleitoral, o interessado ter removido determinado conteúdo da internet, deverá requerer tal ação perante a Justiça comum (art. 38, $\S \S 4^{\circ}$ e $7^{\circ}$ da Resolução).

Feitas tais considerações, percebe-se, desde logo, que tanto o art. 57-I da Lei das Eleições (quanto o art. 38, $\S \S 4^{\circ}$ e $7^{\circ}$ da Resolução do TSE) se articulam com o disposto no art. 19 do Marco Civil da Internet ${ }^{26}$, que trata da responsabilidade civil dos provedores de aplicação por postagem de conteúdo infringente por terceiros na internet, que ocorre apenas após a inércia do provedor em face de decisão judicial que determine a remoção do conteúdo. Os casos de divulgação material inverídico podem ainda ser resolvidos extrajudicialmente, bastando notificar o provedor, para que o conteúdo seja retirado de circulação (notice and take down). $\mathrm{O}$ que o Marco Civil da Internet define, noutros termos, é possibilidade de

\footnotetext{
26 "Art. 19. Com o intuito de assegurar a liberdade de expressão e impedir a censura, o provedor de aplicações de internet somente poderá ser responsabilizado civilmente por danos decorrentes de conteúdo gerado por terceiros se, após ordem judicial específica, não tomar as providências para, no âmbito e nos limites técnicos do seu serviço e dentro do prazo assinalado, tornar indisponível o conteúdo apontado como infringente, ressalvadas as disposições legais em contrário".
} 
responsabilização dos provedores de aplicações, não da retirada de conteúdo per se.

No caso da Resolução, contudo, há que observar que houve a fixação de um prazo especifico para a remoção (máximo de 24 horas), devendo a ordem judicial de remoção apontar se não apenas um prazo específico, como também se identificou a URL (ou, subsidiariamente, a URI ou a URN) como a forma de localização do conteúdo sob judice (GONÇALVES, 2016, p. 148)27.

Note-se, ainda, que o sentido e alcance do art. 19 do Marco Civil da Internet foi submetido, mediante a interposição de dois Recursos Extraordinários, ao crivo do STF, já tendo sido realizada audiência pública, sem que, contudo, tenha sido julgado o mérito, mas com Repercussão Geral reconhecida ${ }^{28}$.

Aqui se verifica mais um elo da legislação eleitoral com o disposto pelo art. 19 do Marco Civil da Internet, o que se pode extrair do $\S 4^{\circ}$ do art. 57-B da Lei das Eleições. Segundo esse dispositivo, caso o provedor de aplicações autorize o impulsionamento pago de conteúdos na sua rede social, também deverá criar um canal de comunicação com os usuários da rede, sendo apenas responsabilizado após o exaurimento do prazo assinalado na ordem judicial para remoção de tal conteúdo impulsionado.

É justamente no que diz respeito ao impulsionamento mediante o uso de tecnologias para promoção de candidatos, partidos políticos ou coligações na internet, bem como a impossibilidade de contratação de terceiro, que eventuais limites fáticos e jurídicos da aplicação da legislação eleitoral para a retirada de conteúdos infringentes se tornam mais evidentes. Quanto à remoção de conteúdo de plataformas de redes sociais abertas - como o são o Facebook, o Twitter -, com edição de conteúdo pelo usuário, é fácil perceber a sua possibilidade.

\footnotetext{
${ }^{27}$ A primeira decisão que removeu informações falsas em período eleitoral das redes sociais, contra a então candidata Marina Silva, durante as campanhas eleitorais em 2018: TSE. RP n. 060054670, decisão monocrática, j. 07.06.2018. Mais um exemplo foi a remoção da informação falsa que afirmava que o então candidato Fernando Haddad estaria divulgando informações falsas de outro então candidato, Jair Bolsonaro: TSE. RP n. 060164660, decisão monocrática, j. 11.10.2018 (TSE, 2018).

${ }^{28}$ O primeiro recurso, RE 1037396, da relatoria do Ministro Dias Toffoli, teve repercussão geral reconhecida e foi interposto pelo Facebook Serviços Online do Brasil Ltda. contra decisão judicial que determinou a exclusão de um perfil falso da rede social e o fornecimento do IP de onde foi gerado. O recurso discute a constitucionalidade do artigo 19 do Marco Civil da Internet (Lei 12.965/2014), que exige prévia e específica ordem judicial de exclusão de conteúdo para a responsabilização civil de provedor de internet, websites e gestores de aplicativos de redes sociais por danos decorrentes de atos ilícitos praticados por terceiros.

No caso do segundo recurso, RE 1057258, relatoria do Ministro Luiz Fux, interposto pela Google Brasil Internet Ltda., o tema de fundo é decisão que reconheceu lesão à honra e à imagem de uma pessoa na criação de uma comunidade da rede de relacionamentos intitulada Orkut e impôs o pagamento de uma indenização ao provedor responsável pela manutenção do serviço.
} 
No entanto, para as redes sociais que operam com aplicativos e softwares de mensagens eletrônicas privadas, as quais não perdem o seu caráter de rede social por se realizar de modo mais privativo - como o é o WhatsApp, Telegram, Messenger e até mesmo o correio eletrônico etc. -, se verifica uma impossibilidade fática para o apagamento desse tipo de conteúdo, de tal sorte que afastada nesses casos a aplicação do art. 57-I da Lei das Eleições. Isso se revela particularmente problemático uma vez que o WhatsApp - um mecanismo de conversação privada - foi palco do maior índice de disseminação de fake news online ao longo do período eleitoral de 2018, tanto pela possibilidade formação de grupos específicos, quanto do estabelecimento de relações de confiança entre os participantes do grupo, ademais da facilidade e rapidez com que as mensagens são encaminhadas.

Em que pese a impossibilidade fática de remoção de conteúdo, o arcabouço normativo eleitoral, legal e infralegal, aponta como vedadas as práticas de disparo de mensagens eletrônicas em massa, incluídas aquelas enviadas através de mecanismos de conversação privada sem concordância do destinatário das mensagens, destacando-se que essa orientação decorre diretamente do art. 34 da Resolução do TSE acima referida, não tendo fundamento direto na lei.

Todavia, considerando as lacunas de regulação legal e o caráter muito aberto de alguns dispositivos, ademais da dificuldade de o legislador acompanhar com a rapidez necessária os desenvolvimentos tecnológicos, tem cabido às Resoluções do TSE regular com detalhes o processo eleitoral para cada pleito, como se dá precisamente no caso do regrado pelo art. 57-J da Lei das Eleições, sem que se vá aqui adentrar a polêmica do alcance da força normativa de tal regulação infralegal e sua legitimidade, em especial quando em causa restrições a direitos fundamentais.

É nessa linha que o art. 34 da Resolução, prevê, para as eleições de 2020, que é "vedada a realização de propaganda via telemarketing em qualquer horário, bem como por meio de disparo em massa de mensagens instantâneas sem anuência do destinatário", o que encontra seu fundamento na proteção do direito fundamental à privacidade $(\mathrm{CF}$, art. 5은 $\mathrm{X}$ e XI), a vedação da perturbação do sossego em períodos eleitorais (Código Eleitoral, art. 243, VI), além do próprio art. 57-J, da Lei das Eleições.

Ainda assim, conforme aponta a mesma Resolução, mensagens eletrônicas privadas, trocadas consensualmente entre pessoas naturais, seja ou não em grupos, não se submetem à Resolução. Ou seja, caso pessoas naturais venham a divulgar notícias falsas entre si de modo privado, além de tais mensagens não serem classificadas como propaganda eleitoral e de não poderem ser removidas por impossibilidade fática em razão do design dessas redes, ocorre que caso não sejam classificadas como impulsionamento (disparo) de mensagens, elas não se submetem à vedação da Resolução referida.

Além disso, é de se sublinhar que o indivíduo que produzir ou compartilhar fake news em períodos eleitorais, com o objetivo de ofender sua lisura, poderá 
incorrer nas sanções dos arts. 323, 324, 325 e 326, do Código Eleitoral, ou, subsidiariamente, as apontadas no Código Penal dentre as hipóteses dos crimes contra a honra. No mais, ressalta-se o trabalho realizado pelas agências de verificação de fatos ${ }^{29}$, auxiliando na higidez do diálogo democrático, precipuamente no que toca às novas ágoras digitais, bem como pela inserção, por parte dos provedores de conteúdo, de tags e avisos em publicações nas mídias sociais, no sentido de que a veracidade dos fatos ali narrados estão sendo contestados naquele momento da leitura pelo usuário. No caso das redes sociais privativas, o alerta disparado informa que a mensagem sob suspeita de falsidade já foi encaminhada muitas vezes, permitindo que sua veracidade seja mais bem apreciada pelo intérprete receptor da mensagem.

Percebe-se, portanto, o paulatino crescimento dos desafios postos à democracia, em especial no que diz com o exercício das liberdades fundamentais de expressão e de informação, problema que também foi submetido ao TSE (que editou a Resolução já referida) e ao STF, que já se pronunciou sobre a matéria no paradigmático caso da ADI 4451 (DF), versando sobre a veiculação de opiniões, sátiras e charges por meio de montagens ou trucagem ou outro mecanismo que permita a ridicularização de candidatos durante o pleito eleitoral.

\subsection{O PROBLEMA DAS FAKE NEWS NO TSE E STF}

Antes de adentrar a análise da decisão paradigmática do STF na ADI 4451 (DF), cabe pontuar que no âmbito da Justiça Eleitoral, designadamente do TSE, não se localizou algum julgamento de mérito do plenário sobre casos envolvendo a retirada de algum conteúdo identificado como sendo uma fake news, mas sim, uma série de decisões monocráticas, inexistindo, portanto, o que se pode designar de um leading case consistente sobre a matéria ${ }^{30}$. Nesse mesmo contexto, é de se referir um pedido de consulta submetido ao TSE sobre o tema, o qual, contudo, foi rejeitado sem resolução do mérito ${ }^{31}$.

Mas os mais importantes casos tramitando no TSE, que, em alguma medida, também envolvem mensagens com natureza de fake news, ainda estão pendentes de

\footnotetext{
${ }^{29}$ Dentre as agências de verificação de fatos, destacam-se a The International Fact-Checking Network, sediada no Poynter Institute, e, no Brasil, as agências Lupa, Aos Fatos e Agência Pública.

${ }^{30} \mathrm{~A}$ partir da pesquisa por palavras-chave, na Pesquisa na JE, apenas no âmbito do TSE, selecionando-se todas os tipos de decisões, por "fake news", "notícias falsas" e "desinformação", separadamente e em sequência, foram identificadas, até a data de 17.05.2020, 83 resultados de decisões monocráticas para "fake news", 45, para "notícias falsas", e, também 45, para "desinformação", todas voltadas à resolução de casos de retirada de fake news de circulação seja nas redes sociais, ou em propagandas eleitorais.

${ }^{31} \mathrm{O}$ partido NOVO ingressou com um pedido de informações sobre medidas adotadas pelo TSE a fim de coibir-se a disseminação de notícias falsas, mas tal pedido foi rejeitado preliminarmente pois as perguntas não eram próprias de uma consulta, porquanto de caráter fático, restando o exame impossibilitado, cf. BRASIL, Tribunal Superior Eleitoral. Consulta nํㅜ 060101871, 2018.
} 
julgamento, destacando-se o julgamento das Ações de Investigação Judicial Eleitoral - Aije n. 0601369-44 e Aije 0601401-49 -, da relatoria do Ministro Og Fernandes, que tem por objeto a impugnação da chapa Bolsonaro-Mourão por contratações não declaradas para o envio em massa de mensagens e de ataques virtuais a adversários eleitorais. Atualmente, o processo encontra-se com o Ministro Edson Fachin, em função de um pedido de vista após um voto para arquivamento do Ministro relator.

Outro caso relevante, mas também inconcluso, desta feita em tramitação no STF, designadamente o Inq 4781, instaurado de ofício pelo atual Presidente da Corte, Ministro Dias Toffoli, mediante a Portaria GP n. 69/2019, que tem como objetivo a investigação de ameaças, notícias fraudulentas contra ministros do STF e seus familiares, incluindo também os vazamentos de informações sigilosas, bem como esquemas de financiamento de disparo de mensagens fraudulentas em massa, em redes sociais, com o objetivo de causar dano ao Estado democrático de Direito (BRASIL, 2019).

Já no âmbito do Congresso Nacional, é de destacar a criação, em setembro de 2019, de uma Comissão Parlamentar Mista de Inquérito - CPMI sobre fake news, cuja finalidade é investigar, dentro de um prazo de 180 dias, ataques virtuais contra a democracia, a partir do uso de perfis falsos, da prática de cyberbullying, assim como a instigação de menores para o cometimento de crimes de ódio (BRASIL, Senado Federal. Comissão Parlamentar Mista de Inquérito - Fake News, 2019).

Assim, considerando a inexistência de uma regulação suficientemente adequada, a ausência de uma orientação firme por parte do TSE, é o caso de voltar a atenção ao decidido pelo STF na ADI 4451, versando sobre o uso de sátiras, charges e montagens, instrumentos os quais mormente utilizados pela imprensa humorística, que, por ora, assumiu a condição de paradigma para o enfrentamento da matéria pelas demais instâncias da Justiça Eleitoral, mas também, em certo sentido, para o legislador e os partidos políticos. A despeito disso, chama a atenção que a Corte, mesmo nesse julgado, não adentrou o tema das fake news de modo mais aprofundado, ao contrário do que se esperava.

Quando do julgamento da ADI 4451/DF, relatada pelo Ministro Alexandre de Moraes, em 20-21.06.2018, o Plenário do STF, confirmou medida cautelar e julgou procedente o pedido formulado para declarar a inconstitucionalidade do inciso II e da segunda parte do inciso III e, por arrastamento, dos $\S \S 4^{\circ}$ e $5^{\circ}$, todos do art. 45 da Lei 9.504/1997, a já referida Lei das Eleições (BRASIL, 2018, p. 23-24).

Tais dispositivos dispõe que as emissoras de rádio e televisão, em sua programação normal e noticiário, a partir de $1^{\mathrm{o}}$ de julho do ano da eleição, não poderão: $(i)$ "usar trucagem, montagem ou outro recurso de áudio ou vídeo que, de qualquer forma, degradem ou ridicularizem candidato, partido ou coligação, ou produzir ou veicular programa com esse efeito" (inciso II) e (ii) "difundir opinião favorável ou contrária a candidato, partido, coligação, a seus órgãos ou 
representantes" (segunda parte do inciso III) ${ }^{32}$. Os $\S \S 4^{\mathrm{o}}$ e $5^{\mathrm{o}}$ explicam o que se entende, respectivamente, por trucagem e por montagem.

Todavia, um olhar mais atento sobre o conteúdo dos votos e do pedido formulado pela ABERT (Associação Brasileira de Emissoras de Rádio e Televisão) revela que o objeto do pedido dizia respeito apenas ao inciso II, este na sua integralidade, bem como à segunda parte do inciso III, sobre difusão de opiniões por jornalistas. Em outras palavras, o pedido não abarcava a primeira parte do inciso III, sobre veiculação de propaganda política pelas emissoras de rádio e televisão.

No que toca ao teor da decisão, acabou por prevalecer o entendimento do relator, Ministro Alexandre de Moraes, cujo voto contemplou a suspensão da eficácia da totalidade tanto do inciso II como do inciso III, integrando assim, de modo extra petita, a veiculação de propaganda política, além da inclusão, por arrastamento, dos $\S \S 4^{\mathrm{o}}$ e $5^{\circ}$, todos do art. 45, da Lei das Eleições. Muito embora o Ministro Edson Fachin tenha chamado atenção no sentido de que a medida (suspensão da eficácia, por inconstitucionalidade) devesse ser concedida apenas quanto à parte final do inciso III, sendo aqui acompanhado por outros ministros (Roberto Barroso, Rosa Weber, Luiz Fux, Gilmar Mendes e Cármen Lúcia) (BRASIL, 2018 , p. $23-25,37,42,45,70,82,129,162)$, existindo, portanto, maioria para a suspensão da eficácia apenas da segunda parte do inciso III, da integralidade do inciso II, e, por arrastamento, dos $\S \S 4^{\circ}$ e $5^{\circ}$ do art. $45^{33}$. Importa chamar a atenção para o fato de que o equívoco acima referido consta tanto na ementa, como nas atas da decisão.

De modo especial, é relevante o fato de que o STF afastou a vedação legal impostas às emissoras de rádio e televisão de veicular programas de humor envolvendo candidatos, partidos e coligações nos três meses anteriores ao pleito, como forma de evitar que sejam ridicularizados ou satirizados. Com a decisão, foi tornada definitiva a suspensão determinada em sede de cautelar pelo Ministro Ayres Britto em 2010, não tendo a proibição sido aplicada desde então.

A teor do voto do Ministro Alexandre de Moraes, relator, a CF proíbe toda e qualquer forma de censura à liberdade de expressão e de informação, incluindo aqui a liberdade, de criação (liberdade artística), destacando, ainda, inexistir permissão que possa ser deduzida do texto constitucional para o efeito de limitar preventivamente o conteúdo do debate público por conta de conjecturas em torno de eventuais efeitos que a divulgação de determinados conteúdos possa vir a ter na esfera pública.

\footnotetext{
${ }^{32}$ Na sua versão integral, o inciso III também estabelece que é vedado "III - veicular propaganda política ou difundir opinião favorável ou contrária a candidato, partido, coligação, a seus órgãos ou representantes" (grifou-se).

${ }^{33}$ Não destacaram, em seus votos, que apenas parte do inciso II estaria sob análise: Ministros Alexandre de Moraes, Dias Toffoli, Ricardo Lewandowski, Marco Aurélio Mello e Celso de Mello.
} 
Ainda para o relator, a liberdade de crítica deve ser plena e irrestrita, abarcando também manifestações de caráter humorístico e satírico, inclusive mediante a utilização de trucagem, montagem ou outros recursos de áudio e vídeo, não havendo razão para que tais práticas sejam interrompidas no período eleitoral, até mesmo pelo fato de que eventuais abusos serão sempre passíveis de eventual responsabilização cível ou mesmo criminal por terem cunho injurioso, difamatório ou mesmo configurarem calúnia.

Passando agora aos votos dos demais julgadores, inicia-se com o do Ministro Gilmar Mendes (BRASIL, 2018, p. 83 e ss.), para quem, mesmo em se levando em conta a possibilidade de veiculação de fake news mediante o recurso a truques, montagens e afins, o ordenamento jurídico brasileiro já fornece mecanismos suficientes para que se constate e combata excessos no exercício da liberdade de expressão, não apenas com o manejo do direito de resposta, tanto na imprensa, como no processo eleitoral, mas também na responsabilidade criminal a posteri, ademais dos outros instrumentos destinados a conter o uso abusivo das liberdades de expressão e de informação, previstas no próprio art. 45 da Lei das Eleições ${ }^{34}$. Nessa linha de argumentação, o Ministro Gilmar Mendes entendeu ser desproporcional a limitação e, consequentemente, violação da liberdade de expressão por meio do disposto nos incisos II e III do art. 45, da Lei das Eleições, restando configurada a sua inconstitucionalidade (BRASIL, 2018, p.129).

Importa acrescentar que o Ministro Gilmar Mendes, aderindo aqui ao voto do relator, destacou que é no caso concreto que os juízes eleitorais devem aferir a ocorrência de abusos passíveis de sanção, posto que não se estaria a permitir uma espécie de vale-tudo, o que, ao fim e ao cabo, guarda sintonia com a posição do relator quando sublinha a possibilidade de uma responsabilização por eventuais abusos.

Na mesma linha, mais focado na importância (e posição preferencial) da liberdade de expressão e de informação para uma ordem democrática, sobressai-se o voto do Ministro Barroso que identificou três erros nos quais o legislador brasileiro incorreu na formulação dos dispositivos analisados (BRASIL, 2018, p. 39) $)^{35}$. Ao apontar os equívocos, o Ministro Barroso considerou errônea a opção do legislador ao colocar a lisura do pleito eleitoral como hierarquicamente superior às liberdades de expressão, incluindo a liberdade artística, de modo a atingir inclusive

\footnotetext{
34 “(...) IV - dar tratamento privilegiado a candidato, partido ou coligação; V - veicular ou divulgar filmes, novelas, minisséries ou qualquer outro programa com alusão ou crítica a candidato ou partido político, mesmo que dissimuladamente, exceto programas jornalísticos ou debates políticos; VI - divulgar nome de programa que se refira a candidato escolhido em convenção, ainda quando preexistente, inclusive se coincidente com o nome do candidato ou com a variação nominal por ele adotada. Sendo o nome do programa o mesmo que o do candidato, fica proibida a sua divulgação, sob pena de cancelamento do respectivo registro".

${ }^{35} \mathrm{O}$ Ministro Luiz Fux também identificou a posição preferencial da liberdade de expressão em seu voto, v. BRASIL. Supremo Tribunal Federal. ADI 4451/DF, 2018, p. 63.
} 
o núcleo essencial das referidas liberdades, desrespeitando a sua posição preferencial, que subsiste por motivos histórico-constitucionais, sendo, ademais, fundamental para o exercício de outras liberdades (BRASIL, 2018, p. 39-40).

A Ministra Rosa Weber, por sua vez, acertadamente aponta, quanto ao direito de resposta, que este nem sempre será eficaz, como no caso de charges e sátiras, mas que tais informações devem ser recebidas pelo destinatário como elas, de fato, o são: simplesmente humor. A Ministra, também destacou que a medida editada pelo legislado, com o escopo de proteger o processo eleitoral é ínfima no que diz com seu impacto sobre a liberdade de expressão, uma vez que a formação do juízo eleitoral dos indivíduos se dá não apenas pela imprensa, mas, de modo muito mais marcante, por meio da internet (BRASIL, 2018, p. 48).

Foi, contudo, no voto proferido pelo Ministro Luiz Fux ${ }^{36}$ que a questão das fake news adquiriu um espaço maior, para quem a intervenção do Poder Judiciário no processo eleitoral deve ser mínima (BRASIL, 2018, p. 63), em especial quando em causa a liberdade de expressão, em relação de retroalimentação com a Democracia. Para Luiz Fux, o objeto da ADI inclui a avaliação do cabimento ou não do humor (ou, "deformação humorística") na imprensa (BRASIL, 2018, p. 64).

Da mesma forma há que frisar a distinção traçada pelo Ministro Luiz Fux entre o exercício legítimo da liberdade de expressão, que abarca a veiculação de opiniões e críticas mediante charges e sátiras, do falseamento doloso da verdade que causa danos graves e mesmo irreversíveis aos candidatos e ao próprio processo eleitoral, as assim designadas fake newws, que devem ser repudiadas e combatidas pela Justiça Eleitoral (BRASIL, 2018, p. 73).

O Ministro Ricardo Lewandowski, por seu turno, ressaltou a conexão das sátiras com as fake news, visto que estas podem ser veiculadas por meio daquelas, ou, alternativamente, que as sátiras transmitam fake news (BRASIL, 2018, p. 35). Os Ministros Marco Aurélio e Cármen Lúcia igualmente sustentaram a inconstitucionalidade dos dispositivos analisados, destacando a importância do riso e do humor para uma sociedade democrática (BRASIL, 2018, p. 160).

Particularmente enfáticas foram as palavras do Ministro Celso de Mello, que no seu voto afirmou que "nenhuma autoridade, mesmo a autoridade judiciária, pode prescrever o que será ortodoxo em política ou em outras questões que envolvam temas de natureza filosófica, ideológica ou confessional, nem estabelecer padrões de conduta cuja observância implique restrição aos meios de divulgação do pensamento" (BRASIL, 2018, p. 148). Para o Decano do STF,

\footnotetext{
${ }^{36}$ Nas palavras do ministro Luiz Fux, em uma antecipação de voto, não se pode "chancelar" as fake news (p. 73), podendo estas serem inclusive chamadas de "notícias fraudulentas", concordando com o Ministro Dias Toffoli (p. 74), que interviu em sua fala, as quais, vale dizer, não se confundem com a sátira, manejadas a partir da liberdade artística dos jornalistas humorísticos.
} 
O riso, por isso mesmo, deve ser levado a sério, pois constitui, entre as várias funções que desempenha, o papel de poderoso instrumento de reação popular e de resistência social a práticas que caracterizam ensaios de dominação governamental, de opressão do poder político, de abuso de direito ou de desrespeito aos direitos dos cidadãos (...) O recurso à derrisão, no âmbito político-eleitoral, constitui, na perspectiva de uma dialética do humor, verdadeira antítese ao que é grotesco, ao que é desonesto, ao que é fraudulento, ao que é abusivo, ao que é enganador. Em uma palavra: o riso e o humor são expressões de estímulo à prática consciente da cidadania e ao livre exercício da participação política, enquanto configuram, eles próprios, manifestações de criação artística. O riso e o humor, por isso mesmo, são transformadores, são renovadores, são saudavelmente subversivos, são esclarecedores, são reveladores. É por isso que são temidos pelos detentores do poder ou por aqueles que buscam ascender, por meios desonestos, na hierarquia governamental (BRASIL. Supremo Tribunal Federal. ADI 4451/DF, 2018, p. 133-134).

À vista da síntese da decisão na ADI 4451/DF, verifica-se que a despeito de sua relevância e das posições de alguns dos Ministros (Alexandre de Moraes, Luiz Fux, Dias Toffoli, Ricardo Lewandowski, Gilmar Mendes) contrárias a veiculação de fake news (BRASIL, 2018, p. 16, 53, 71-72, 76-78) no processo eleitoral, o julgado do STF, em que pese articular alguma linha de orientação, não adentra o tema com maior detalhamento, em especial no que concerne ao combate das fake news nas mídias sociais, de tal sorte que também na seara jurisprudencial, ao menos por ora, não se encontram elementos mais robustos e estáveis a permitirem o melhor enfrentamento do problema pelas Instâncias da Justiça Eleitoral, mas também naquilo em que as fake news também guardam relação com outras searas do direito, v.g. civil e penal.

De todo modo, inegável se tratar da primeira importante decisão do STF sobre a matéria e sobre a legitimidade prima facie da veiculação de sátiras, charges e manifestações de humor em geral durante campanhas eleitorais, ademais de reafirmar a posição preferencial da liberdade de expressão na arquitetura constitucional brasileira.

Assim sendo, as lacunas de regulação quanto ao uso de fake news em geral e, em particular, no domínio das redes sociais online, persiste e desafia todos os protagonistas da esfera jurídica a equacionar o problema.

5. AS FAKE NEWS E A DIFÍCIL TAREFA DE CONCILIAR A DEMOCRACIA E AS SUAS INSTITUIÇÕES COM A LIBERDADE DE EXPRESSÃO E DE INFORMAÇÃO

Como já adiantado, embora a liberdade de expressão e de informação seja estruturante e mesmo condição de possibilidade da democracia, o seu manejo 
abusivo também pode colocar a democracia e suas instituições (dentre elas a própria liberdade de expressão e informação) em grave risco. Nesse contexto, calha lembrar a lição de Machado (2007, p. 473), no sentido de que a liberdade de expressão possui duas dimensões, designadamente, uma de natureza individual, na perspectiva da qual a liberdade de expressão é um meio para o desenvolvimento da personalidade, a outra de caráter transindividual, ou seja, a dimensão democrático-fundamental, que resguarda o desenvolvimento da opinião pública e do engajamento da participação política. Na mesma senda, Dimoulis e Martins (2006, p. 274) utilizam a expressão liberdade funcional, para atrelá-la ao processo democrático, no seu aspecto objetivo, ao passo que na sua faceta individual, que diz respeito ao livre desenvolvimento da personalidade, a associam à dimensão jurídico-subjetiva.

Todavia, para que as liberdades de expressão e de informação, nas suas duas dimensões acima referidas, possam cumprir com sua função na ordem jurídicoconstitucional, necessárias "garantias de organização e de processos com transparência democrática (princípio majoritário, publicidade crítica, direito eleitoral)" (CANOTILHO, 2000, p. 291). Isso, por sua vez, remete ao problema da regulação e dos limites que podem ser impostos legitimamente à liberdade de expressão e de informação, em especial, no que interesse ao presente texto, das assim chamadas fake news.

Um primeiro ponto a ser sublinhado, diz respeito ao fato de que não apenas o conteúdo da informação ou manifestação do pensamento é abarcado pelo âmbito de proteção das respectivas liberdades fundamentais, mas também o meio para tanto, o modo pelo qual se transmite informações e opiniões (SARLET, 2018, p. 497498), o que cresce em importância quando se trata da expansão da digitalização e, em especial, das mídias sociais na internet e com o crescimento exponencial do número de usuários, conforme, aliás, referido e documentado no item 3.1.

Em virtude de tal fenômeno, a democratização do acesso à internet e de todo o fluxo informacional que nela se processa, ademais da possibilidade de uma intervenção ativa por parte de indivíduos e grupos que não integram órgãos da mídia (imprensa, em sentido amplo), levaram (e seguem levando) a uma intensa e aparentemente irreversível - descentralização informacional, que, todavia, impacta, em maior ou menor medida, a credibilidade "daqueles que tradicionalmente eram encarados como guardiães do que poderíamos chamar de verdade objetiva dos fatos" (jornais, televisões, rádio, etc.) (WAACK, 2018, p. 124).

Diretamente relacionada a tal processo de descentralização radicalizado pela internet e mídias sociais, está a perda, em maior ou menor medida, da acuracidade da informação veiculada, visto ser desproporcional (além de praticamente incontrolável) exigir-se de todo e qualquer indivíduo um exercício de avaliação crítica profunda relativamente a cada informação acessada (mas também postada) na Internet, o que se agrava considerando a larga desigualdade em termos de capacidade informacional entre as pessoas (BALEM, 2017, p. 5). 
Nesse contexto, torna-se cada vez mais complexo e difícil assegurar a todos ampla liberdade de expressão e de informação, de modo a salvaguardar a democracia e suas instituições (dentre as quais desponta a assim chamada imprensa livre), e, ao mesmo tempo, também com o escopo de, ao fim e ao cabo, manter a higidez do binômio liberdade de expressão e democracia, defender a opinião pública do perigo resultante da manipulação deliberada por pessoas ou grupos de interesse, bem como de sugestões de ideologias nebulosas que, na maioria das vezes, refletem a nostalgia de situações históricas do passado (PÉREZ LUÑO, 1999, p. 206).

Com isso, é claro, não se está a afirmar a existência de um dever de informar e expressar apenas a verdade, no sentido da afirmação de fatos comprovados e comprováveis, não só, mas também, à vista da circunstância de que temas controversos e questões polêmicas, assim como dissensos ideológicos mesmo agudos, são próprios (e indispensáveis) a uma democracia e integram o regular andamento dos processos eleitorais (BRITO; LONGHI, 2014, p. 113).

O desafio, contudo, está em se distinguir o polêmico do falso (distorcido, manipulado com vistas à desinformação e provocação de terminados resultados), o que diz respeito ao problema de como e em que medida a maior ou menor capacidade crítica dos indivíduos, por sua vez, relacionada aos níveis de desigualdade cultural e econômica, impacta as suas opções políticas, de modo especial em face da sedução permanente dos discursos que apelam aos sentimentos e instintos, típicos de regimes autoritários e/ou populistas.

Não é à toa, portanto, que se tenha afirmado que "a democracia não se limita à realização de eleições livres e periódicas. O ambiente democrático, requer, doravante, a existência de um espaço público consolidado, em que os temas de interesse geral possam ser debatidos com liberdade” (BALEM, 2017, p. 5). Nessa mesma perspectiva, calha invocar a lição de SUNSTEIN, para quem "o objetivo da liberdade de expressão é, em parte, fomentar a autonomia política; uma democracia em bom funcionamento não é possível a menos que as pessoas possam dizer o que pensam, mesmo que seus pensamentos sejam falsos. Mas se as pessoas espalharem boatos falsos - mais obviamente sobre autoridades e instituições públicas - a própria democracia sofrerá" (SUNSTEIN, 2010, p. 13).

É por tal razão que se pode comungar do ponto de vista de que, não só mas em especial nas eleições, a disseminação de falsidades mediante o exercício do direito à liberdade de expressão e de informação represente fator de distorção que, em maior ou menor medida, contamina - considerando que boatos e mentiras sejam divulgados e em muitos casos assim recebidos (KAKUTANI, 2018, p. 19-20) - o acesso à informação e o exercício consciente e crítico do direito ao sufrágio. Afinal, para o constante aperfeiçoamento da capacidade crítica, os indivíduos devem ter acesso a mais ampla possível gama de informações (MACHADO, 2007, p. 476).

Isso, por sua vez, remete ao problema complexo e altamente sensível da regulação do discurso, designadamente quando se trata de regulação que tenha 
como objeto o conteúdo, porquanto associada diretamente à discussão sobre a censura, mas que aqui não será desenvolvido. No que concerne ao processo eleitoral e o recurso às fake news, assume destaque a já referida e já avançada universalização do acesso à Internet em escala global, mas também no Brasil, como bem atestam os dados referentes ao último período eleitoral colacionados no item 3.1 supra.

Nesse cenário eleitoral das redes, portanto, encontram-se não apenas os partidos políticos e os candidatos, como também o povo, a mídia, grupos organizados e os provedores de conteúdo (BRITO; LONGHI, 2014, p. 67). Sabendo que o uso da internet no Brasil é massificado - em processo paulatino de universalização -, cabe afirmar que nas mais variadas redes é possível encontrar usuários das mais diversas classes sociais, com uma altamente diversificada gama de opiniões, lastreadas em um amálgama de elogios e ácidas críticas (BRITO; LONGHI, 2014, p. 118). Repisa-se que a limitação do debate eleitoral, ao se impor limitações no exercício da liberdade e pluralidade de opiniões, pode implicar défices quanto ao seu grau de legitimidade, o que não afasta a necessidade de coibir a veiculação de informações falaciosas destinadas a comprometer a lisura do embate político e, portanto, até mesmo a legitimidade dos seus resultados.

Nesse contexto, é de se recuperar alguns dos dados já colacionados, lembrando que mediante a pesquisa realizada pelo Instituto Datafolha nas redes sociais durante as eleições brasileiras de 2018, o aplicativo de mensagens privadas Whatsapp se revelou ser a rede mais utilizada pelos eleitores, dos quais 65\% têm conta no aplicativo, sendo que $24 \%$ o utilizam para envio e troca de informações sobre políticas e eleições (INSTITUTO DATAFOLHA, 2018, p. 2).

Igualmente relevante é destacar como as pessoas costumam agir e reagir em relação às fake news. Nessa perspectiva, acompanhando WARDLE, é possível arrolar as seguintes maneiras como as pessoas recebem e compreendem as desinformações e que podem ser agrupadas em seis pontos principais: (i) reputação da informação, com base na familiaridade; (ii) endosso com base na crença de outras pessoas com as quais há uma relação de confiança; (iii) consistência, com a verificação de a informação estar replicada em múltiplos lugares; (iv) violação de expectativa, caso o suporte da informação, no caso, em um site, se apresenta de modo esperado; (v) autoconfirmação, com base no viés da confirmação de crenças que um indivíduo possua; e, por fim, (vi) intenção persuasiva do suporte informativo tornar-se uma efetiva fonte de informação (WARDLE, 2017, p. 45). Percebe-se, assim, que os usuários tendem a não "questionar a credibilidade da informação, a menos que ela viole suas preconcepções ou se eles são incentivados para tanto" (Traduziu-se. LAZER; BAUM; BENKLER, 2018, p. 1095) ocasionando um problema sistêmico (KAKUTANI, 2018, p. 15).

Em face das considerações tecidas até o momento, o que se verifica é a necessidade de se buscar alternativas juridicamente legítimas e, ademais disso, eficazes, para o combate da disseminação de informações falsas no ambiente digital. 
Em que pese a legislação brasileira já tenha adotado um mecanismo - a persecução penal -, esta não se mostra a mais adequada frente a um direito penal de ultima ratio, além da sua fragilidade em termos de eficácia, carecendo ser complementada por outros instrumentos.

Ademais, a solução para o problema da disseminação de informações falsas não reside na consequência, mas, sim, na causa. Segundo LAZER, BAUM e BENKLER, existem duas possibilidades de resolução do problema das notícias falsas: aquela voltada para os próprios indivíduos realizarem a avaliação do fluxo informacional, e a que é destinada a criar e promover mudanças estruturais anteriores, operando na esfera da prevenção e do acesso por parte dos indivíduos ao fenômeno da desinformação (2018, p. 1095).

Dada a dificuldade no tocante à sua concretização, a primeira alternativa esbarra no fenômeno da formação de bolhas informacionais e da polarização discursiva. A segunda, por sua vez, faz parte de um processo de conscientização informacional, que, por sua vez, abarca diferentes manifestações, designadamente: (i) a percepção de informações sensacionalistas e da utilização de palavras espalhafatosas, que prendem a atenção do leitor; (ii) a verificação da atualidade da informação, isto é, que ela não foi extraída de um contexto histórico diverso; (iii) a leitura da informação por completo, não apenas do seu título, uma vez que o título pode induzir o leitor a erro; (iv) verificação da fonte da informação, perquirindo a idoneidade do meio comunicativo. Logo, para que haja um ambiente livre de "fake news", deverá haver a atuação direta de "veículos da imprensa, agências de checagem de dados, pesquisadores, especialistas em comunicação digital e empresas detentoras das plataformas sociais" (ALMEIDA, 2018).

Nessa perspectiva, é crucial que o combate às 'fake news' se dê pelos meios legais disponíveis (e adequados, é de se acrescentar) e pela boa imprensa, que rapidamente pode levar a correta notícia à população" (BRASIL. Supremo Tribunal Federal. Informativo 907. ADI 4451/DF, 2018), mas não - pelo menos em regra e à partida - com a sua abrupta e agressiva remoção.

Tal forma de ação, por sua vez, remete à necessidade de contínua vigilância em relação aos perigos da formação de uma ordem orwelliana que determina o que é verdade e o que não é, impedindo a circulação de outros discursos e, com isso, assumindo a feição de uma nova forma de dominação (BALEM, 2017, p. 10).

\section{CONCLUSÃO}

Em apertada síntese, é de se sublinhar, mais uma vez, que embora esteio de uma ordem democrática, a liberdade de expressão e de informação pode, como demonstra o fenômeno das fake news, colocar em risco a Democracia e suas instituições, o que se verifica não só, mas principalmente na esfera do embate político-eleitoral.

Outrossim, ainda que boatos e mentiras não sejam uma forma nova de conduzir o processo eleitoral e de buscar influenciá-lo, a Internet, sua ampliação e 
sofisticação, bem como - e aqui em especial - as redes sociais, viabilizou novas e mais agressivas, ademais de eficazes, possibilidades de, mediante o recurso à desinformação em geral e às fake news em particular, influenciar os resultados das eleições, ainda que não se tenha dados precisos sobre em que medida as fake news sejam determinantes para tanto.

Independentemente disso, não há, pelo menos não num Estado Democrático de Direito que mereça tal designação, abrir mão da garantia plena (no sentido de uma posição preferencial) da liberdade de expressão, que, por sua vez, inclui os modos (meios) pelos quais ela se manifesta, como se dá no caso com as charges, montagens ou uma postagem nas redes sociais, de tal sorte que, como bem pontou o STF na decisão acima apresentada, não há como proscrever o recurso a sátiras e ao humor também no bojo de um processo eleitoral.

Numa primeira linha de orientação, cabe observar que mesmo no caso de mentiras/boatos, em suma, de fake news, não é possível, do ponto de vista constitucional, promover desde logo a sua eliminação e responsabilização dos seus autores, porquanto a liberdade de expressão (incluindo a manifestação de pensamento, comunicação e artística) não protege tão somente o discurso "verdadeiro", cientificamente comprovado, até mesmo pelo fato de ser muitas vezes difícil valorar no que consiste a "verdade".

Note-se ademais disso, que existem múltiplas formas de compreender a verdade, mas deve-se reconhecer, por outro lado, os problemas ocasionados quando a verdade passa a ser pura e simplesmente uma questão de perspectiva. Assim, deve-se reconhecer a legitimidade da verdade racional, lastreada no conhecimento científico, sem, obviamente, negar a existência das então chamadas verdades factuais, decorrentes de interpretações dos indivíduos (ARENDT, 1967; KAKUTANI, 2018).

Ainda nesse contexto, não custa lembrar que aquilo que se tem por verdade é extraído de um conjunto de indicadores, ou seja, de fontes, que, a despeito de sua seriedade também são humanamente falíveis e igualmente se ancoram em outras fontes de natureza diversa. Não é a toa, portanto, que mesmo na seara da ciência, Ilya Prigogine alertou para o fato de que vivemos numa "era das incertezas" (PRIGOGINE, 2011).

Com isso, contudo, não se está a sustentar a tese da impossibilidade jurídica de regulação e da interdição da desinformação e, em especial, das fake news, como se verifica no caso de evidentes excessos discursivos, como se dá com a injúria, a difamação e a calúnia, bem como nos casos de falseamento doloso de informações, voltado à perturbação do processo eleitoral.

Tal regulação, por seu turno, não passa apenas pelo Estado nas suas diversas funções e manifestações, mas também envolve (e até mesmo exige) um controle social, que pode ser mobilizado também pelas mídias sociais on-line, no sentido de uma autorregulação regulada, visto que é nas mídias sociais e mediante elas que se trava, de modo cada vez mais agudo, o embate discursivo eleitoral, ademais de o 
Estado não dispor de instrumentos regulatórios suficientemente abrangentes e eficazes para, sozinho, enfrentar o problema.

Ao fim e ao cabo, é possível confirmar a hipótese formulada ao início, no sentido da existência de lacunas de regulação (legislativa, administrativa, judiciária e autorregulação) e mesmo da, pelo menos parcial ineficácia (inefetividade) do regramento existente na esfera eleitoral para um bom combate, sempre constitucionalmente consistente, das fake news que, por seu conteúdo, representam um claro risco de perturbação do regular transcurso do processo eleitoral, sustentáculo (tal como a liberdade de expressão) do Estado Democrático de Direito instituído pela CF.

À vista disso e além da necessidade da construção de uma dogmática dos direitos fundamentais robusta e constitucionalmente adequada, que, por ora, enquanto se aguarda novo regramento legal (seja corretivo, seja substitutivo ou mesmo complementar), já pode e deve ser acessada pelos que atuam na esfera eleitoral, é também de suma relevância que se coloque a legislação em diálogo mais intenso e coordenado com outros diplomas legais, como é o caso do já referido Marco Civil da Internet, entre outros.

Pese a convocação de outras leis, em especial o Marco Civil da Internet, já esteja ocorrendo no âmbito eleitoral, o fato é que o seu manejo mediante uma exegese sistemática ainda é carente de aperfeiçoamento. Mas tal aspecto, consoante anunciado na introdução, extrapola o objeto do presente texto.

\section{REFERÊNCIAS}

AGRA, Walber de Moura; CAVALCANTI, Francisco Queiroz. Comentários à nova lei eleitoral: Lei n. 12.034, de 29 de setembro de 2009. Rio de Janeiro: Forense, 2010.

ALLCOTT, Hunt; GENTZKOW, Matthew. Social Media and Fake News in the 2016 Election. Journal of Economic Perspectives, v. 31, n. 2, p. 211-36, 2017.

ALMEIDA, Raquel de Q. Fake news: arma potente na batalha de narrativas das eleições 2018. Cienc. Cult, São Paulo, v. 70, n. 2, abr./jun. 2018.

ARENDT, Hannah. Verdade e Política. The New Yorker. Tradução: Manuel Alberto, fev. 1967.

BALEM, Isadora Forgiarini. O Impacto das fake news e o fomento dos discursos de ódio na sociedade em rede: a contribuição da liberdade de expressão na consolidação da democrática. Congresso Internacional de Direito e Contemporaneidade, Santa Maria, 8-10, nov. 2017. 
BARROSO, Luís Roberto. Liberdade de expressão versus direitos da personalidade Colisão de direitos fundamentais e critérios de ponderação. Temas de direito constitucional. Rio de Janeiro: Renovar, 2005. v. 3.

BBC Monitoring; UGC Newsgathering. China coronavirus: Misinformation spreads online about origin and scale. BBC Trending, 30 de janeiro de 2020. Disponível em: bbc.com/news/blogs-trending-51271037. Acesso em: 8 maio 2020.

BOYD, Danah B.; ELLISON, Nicole B. Social network sites: definition, history and scholarship. Washington, D.C., Journal of Computer-Mediated Communication, v. 13, n. 1, p. 210-230, 2008.

BRASIL, Senado Federal. Comissão Parlamentar Mista de Inquérito - Fake News.

Atividades legislativas. Comissões, 2019. Disponível em:

legis.senado.leg.br/comissoes/comissao?0\&codcol=2292. Acesso em: 5 maio 2020.

BRASIL. Supremo Tribunal Federal. ADI 4451, rel. Min. Alexandre de Moraes. Tribunal Pleno, j. 20-21 jun. 2018.

BRASIL. Supremo Tribunal Federal. ADPF 130, rel. Min. Carlos Britto. Tribunal Pleno, j. 30.04.2009.

BRASIL. Supremo Tribunal Federal. ADPF 187, rel. Min. Celso de Mello. Tribunal Pleno, j. 15.06.2011.

BRASIL. Supremo Tribunal Federal. ADI 4815, rela ${ }^{\mathrm{a}}$ Mina ${ }^{\mathrm{a}}$ Cármen Lúcia. Tribunal Pleno, j. 10.06.2015.

BRASIL. Supremo Tribunal Federal. ADI 4451, rel. Min. Alexandre de Moraes. Tribunal Pleno, j. 20-21.06.2018.

BRASIL. Supremo Tribunal Federal. RE 1037396, rel. Min. Dias Toffoli, aguarda julgamento.

BRASIL. Supremo Tribunal Federal. RE 1057258, rel. Min. Luiz Fux, aguarda julgamento.

BRASIL. Supremo Tribunal Federal. Gabinete da Presidência. Portaria GP n. 69, de 14 de março de 2019. Disponível em: conjur.com.br/dl/comunicado-supremo-tribunalfederal1.pdf. Acesso em: 23 maio 2020. 
BRASIL. Supremo Tribunal Federal. Informativo 907. ADI 4451/DF, rel. min. Alexandre de Moraes, julgamento em 20 e 21.6.2018.

BRASIL, Tribunal Superior Eleitoral. Consulta ${ }^{\circ} 060101871$, rel. Min. Tarcisio Vieira de Carvalho Neto, j. 26.09.2018.

BRASIL. Tribunal Superior Eleitoral. Portaria TSE n. 949, de 7 de dezembro de 2017a. Disponível em: justicaeleitoral.jus.br/arquivos/tse-portaria-no949-de-07-de-dezembro-de2017. Acesso em: 10 maio 2019.

BRASIL. Tribunal Superior Eleitoral. Resolução do TSE n. 23.551/2017. Dispõe sobre propaganda eleitoral, utilização e geração do horário gratuito e condutas ilícitas em campanha eleitoral nas eleições. 18 de dezembro de 2017b. Disponível em: tse.jus.br/legislacao-tse/res/2017/RES235512017.html. Acesso em: 20 junho 2019.

BRASIL. Tribunal Superior Eleitoral. Termo de Compromisso - Eleições 2018, jun. 2018 a. Disponível em: justicaeleitoral.jus.br/arquivos/termo-de-compromisso-com-partidospoliticos-contra-noticias-falsas-nas-eleicoes-2018. Acesso em: 12 jun. 2019.

BRASIL. Tribunal Superior Eleitoral. Memorando de Entendimento - Eleições 2018, jun. 2018b. Disponível em: justicaeleitoral.jus.br/arquivos/memorando-de-atendimento. Acesso em: 12 jun. 2019.

BRITO, Auriney; LONGHI, João Victor Rozatti. Propaganda eleitoral na Internet. São Paulo: Saraiva, 2014.

CANOTILHO, José Joaquim Gomes. Direito constitucional e teoria da Constituição. 7. ed. Coimbra: Almedina, 2000.

CASTELLS, Manuel. A sociedade em rede. Tradução por Roneide Venancio Majer. 8. ed. rev. e ampl. São Paulo: Paz e Terra, 2005. v. 1.

CITRON, Danielle K.; CHESNEY, Robert. Deep Fakes: A Looming Challenge for Privacy, Democracy, and National Security. Faculty Scholarship, Boston University School of Law. Draft, 2018. Disponível em: scholarship.law.bu.edu/faculty_scholarship/640/. Acesso em: 20 nov. 2019.

DICE, Mark. The True Story of Fake News: How Mainstream Media Manipulates Millions. The Resistance Manifesto. 2017. 
DIMOULIS, Dimitri; MARTINS, Leonardo. Teoria geral dos direitos fundamentais. São Paulo: RT, 2006.

ECO, Umberto. Der Ewige Faschismus, München: Carl Hanser Verlag, 2020.

EPISTOCRACIA: o ataque dos autoproclamados "fact-checkers" à internet livre. Gazeta do Povo, 2018. Disponível em: gazetadopovo.com.br/vozes/flavio-gordon/epistocracia-oataque-dos-autoproclamados-fact-checkers-internet-livre. Acesso em: 23 maio 2019

FACEBOOK'S fake news experiment backfires. BBC News, 2018. Disponível em: bbc.com/news/technology-41900877. Acesso em: 15 maio 2019

FRANCISCO, Severino. Sociedade da desinformação. Observatório da Sociedade da Informação. Setor de Comunicação e Informação da UNESCO no Brasil. Brasília, 2004. Disponível em: unesdoc.unesco.org/images/0015/001540/154058por.pdf. Acesso em: 07 maio 2020.

FREITAS, Juarez. Sustentabilidade: direito ao futuro. 2. ed. Belo Horizonte: Fórum, 2012.

GABINETE do ódio. Bolsonaristas gastam R $\$ 5$ milhões por mês com fake news, revela inquérito. Revista Consultor Jurídico, 11 de março de 2020. Disponível em: https://www.conjur.com.br/2020-mar-11/empresarios-gastam-milhoes-mes-fake-news.

Acesso em: 15 de março de 2020.

GINGRAS, Richard. Labeling fact-check articles in Google News. Google News Iniciative, out. 2016. Disponível em: blog.google/outreach-initiatives/google-news-initiative/labelingfact-check-articles-google-news/. Acesso em: 14 maio 2019.

GLOBAL WEB INDEX. Daily time spent using social media. Average daily time (in hours and minutes) that internet users aged 16 to 64 spend using social media on any device, January 2020. Disponível em: globalwebindex.com. Acesso em: 25 abr. 2020.

GONÇALVES, Victor Hugo Pereira. Marco civil da internet comentado. São Paulo: Atlas, 2016.

HÄBERLE, Peter. A dignidade humana como fundamento da comunidade estatal. In: SARLET, Ingo Wolfgang (Org.). Dimensões da Dignidade. Ensaios de Filosofia do Direito e Direito Constitucional, Tradução: Ingo Wolfgang Sarlet e Pedro de Mello Aleixo. 2. ed. Porto Alegre: Livraria do Advogado, 2009. 
HARARI, Yuval Noah. 21 Lições para o Século 21. Tradução: Paulo Geiger. São Paulo: Companhia das Letras, 2018.

INICIADO julgamento de ações que pedem a cassação de Jair Bolsonaro e Hamilton Mourão. Comunicação - Tribunal Superior Eleitoral, 26 de novembro de 2019. Disponível em: tse.jus.br/imprensa/noticias-tse/2019/Novembro/iniciado-julgamento-de-acoes-quepedem-a-cassacao-de-jair-bolsonaro-e-hamilton-mourao. Acesso em: 23 maio 2020.

INSIDE the world of Brazil's social media cyborgs. BBC News, 2018. Disponível em: bbc.com/news/world-latin-america-42322064. Acesso em: 3 jun. 2019. Também, EXCLUSIVO: investigação revela exército de perfis falsos usados para influenciar eleições no Brasil. BBC News, 2018. Disponível em: bbc.com/portuguese/brasil-42172146. Acesso em: 5 jun. 2019.

INSTITUTO DATAFOLHA. Eleições 2018. Pesquisa Redes sociais. 2018. Disponível em: media.folha.uol.com.br/datafolha/2018/10/27/44cc2204230d2fd45e18b039ee8c07a6.pdf. Acesso em: 10 maio 2019.

KAKUTANI, Michico. A morte da verdade: notas sobre a mentira na era Trump. Tradução: André Czarnobai e Marcela Duarte. Rio de Janeiro: Intrínseca, 2018.

KLEIN, David O.; WUELLER, Joshua R. Fake news : a legal perspective. Journal of Internet Law, v. 20, n. 10, p. 5-15, 2017. Disponível em: http://governance40.com/wpcontent/uploads/2018/12/Fake-News-A-Legal-Perspective.pdf. Acesso em: 15 junho 2019.

LAZER, David M. J.; BAUM, Matthew A.; BENKLER, Yochai, et. al. The science of fake news, Science, v. 359, i. 6380, pp. 1094-1096, 2018.

LEITER, Brian. Cleaning cyber-cesspool: Google and Free Speech. In: LEVMORE, Saul; NUSSBAUM, Martha C. (coord.) The offensive internet: speech, privacy, and reputation. Library of Congress. 2010.

MACHADO, Jónatas E. M. Liberdade de expressão: dimensões constitucionais da esfera pública no sistema social. Coimbra: Coimbra, 2002.

MACHADO, Jónatas E. M. Liberdade de programação televisiva: notas sobre seus limites constitucionais negativos. In: SARLET, Ingo W. (Org.). Direitos fundamentais, informática e comunicação. Porto Alegre: Livraria do Advogado, 2007. 
MICHELMAN, Frank I. Relações entre democracia e liberdade de expressão: discussão de alguns argumentos. In: SARLET, Ingo Wolfgang. (Org.). Direitos fundamentais, informática e comunicação. Porto Alegre: Livraria do Advogado, 2007.

OEA diz que uso de fake news nas eleições do Brasil é 'sem precedentes'. Veja, 2018. Disponível em: veja.abril.com.br/politica/oea-diz-que-uso-de-fake-news-nas-eleicoes-dobrasil-e-sem-precedentes/. Acesso em: 17 maio 2019.

PARISER, Eli. The user is the content. In: PARISER, Eli. The filter bubble: what is the internet hiding from you. New York: Penguin Press, 2011.

PEREIRA DA SILVA, Jorge. 'Fake news' conquistam 2017. O Jornal Económico, 17 Novembro 2017. Disponível em: jornaleconomico.sapo.pt/noticias/fake-news-conquistam2017-233751. Acesso em: 10 dez. 2019.

PÉREZ LUÑO, Antonio Enrique. Derechos humanos, Estado de Derecho y Constitución. 6. ed. Madrid: Tecnos, 1999.

PENNYCOOK, Gordon; EPSTEIN, Ziv, MOSLEH, Mohsen; ARECHAR, Antonio A.; ECKLES, Dean; RAND, David G. Understanding and Reducing the Spread of Misinformation Online. PsyArXiv, 13 de novembro de 2019.

PÉREZ LUÑO, Antonio-Enrique. Teledemocracia, ciberciudadania y derechos humanos. Revista Brasileira de Políticas Públicas, Brasília, v. 4, n. 2, 2014.

PRIGOGINE, Ilya. O fim das certezas: tempo, caos e as leis da natureza. 2 ed. São Paulo: UNESP, 2011.

RAMALHO, Renan. PT, PCO, PSTU e PTC não assinam compromisso contra disseminação de conteúdos falsos, diz TSE. G1 - Globo, 4 de outubro de 2018. Disponível em: $\quad$ g1.globo.com/politica/eleicoes/2018/noticia/2018/10/04/pt-pco-pstu-e-ptc-naoassinam-compromisso-contra-disseminacao-de-fake-news.ghtml. Acesso em: 18 dez. 2018

SARLET, Ingo Wolfgang; FERREIRA NETO, Arthur. O direito ao "esquecimento" na sociedade da informação. Porto Alegre: Livraria do Advogado, 2018.

SARLET, Ingo Wolfgang. Direitos fundamentais em espécie. In: SARLET, Ingo Wolfgang; MARINONI, Luiz Guilherme; MITIDIERO, Daniel. Curso de direito constitucional. 7. ed. São Paulo: Saraiva, 2018. 
SARLET, Ingo Wolfgang; WEINGARTNER NETO, Jayme. Democracia desmascarada? Liberdade de reunião e manifestação: uma resposta constitucional contra-hegemônica. In: Clève, Clèmerson Merlin; Freire, Alexandre (Coord.). Direitos fundamentais e jurisdição constitucional. São Paulo: Ed. RT, 2014.

SARMENTO, Daniel. Art. $5^{\circ}$, caput IV In: CANOTILHO, José Joaquim Gomes; MENDES, Gilmar Ferreira; SARLET, Ingo Wolfgang; STRECK, Lenio (coord.). Comentários à Constituição do Brasil. São Paulo: Saraiva, 2018.

SCHREIBER, Anderson. Direitos da personalidade. 2. ed. rev. e atual. São Paulo: Atlas, 2013.

STATISTICA. Most popular social networks based on share of users in Brazil in 2018, November 2018. Disponível em: statista.com/statistics/754471/brazil-penetration-socialnetworks/. Acesso em: 25 abr. 2020.

SUNSTEIN, Cass R. A verdade sobre os boatos. Como se espalham e por que acreditamos neles. Rio de Janeiro: Elsevier, 2010.

TANDOC JR., Edson C.; LIM, Zheng Wei; LING, Richard. Defining “Fake News", Digital Journalism, v. 6, n. 2, p. 137-153, 2018.

TSE aplica pela primeira vez norma que coíbe notícias falsas na internet. TSE Comunicação. Disponível em: tse.jus.br/imprensa/noticias-tse/2018/Junho/tse-aplica-pela-primeira-veznorma-que-coibe-noticias-falsas-na-internet. Acesso em: 24 maio 2019.

TUFEKCI, Zeynep. Algorithmic harms beyond Facebook and Google: emergent challenges of computational agency. Colo. Tech. L.J. v. 13, p. 203-218, 2015.

UNIÃO EUROPEIA. Council of Europe. Information Disorder Report, nov. 2017. Disponível em: rm.coe.int/information-disorder-report-november-2017/1680764666. Acesso em: 10 jun. 2019.

WAACK, William. Fake News: uma visão político-jornalística, in: ABBOUD, Georges; NERY JR., Nelson; CAMPOS, Ricardo (Coord.), Fake News e Regulação, São Paulo: RT, 2018.

WANG, Amy B. 'Post-truth' named 2016 word of the year by Oxford Dictionaries. The Washington Post, 16 de novembro de 2016. Disponível em: washingtonpost.com/news/the- 
fix/wp/2016/11/16/post-truth-named-2016-word-of-the-year-by-oxford-dictionaries/.

Acesso em: 20 maio 2019.

WARDLE, Claire. Information Disorder. Toward an interdisciplinary framework for research and policymaking. Strasbourg: Council of Europe, 2017.

WORLD HEALTH ORGANIZATION. Ten threats to global health in 2019, janeiro de 2019. Disponível em: https://www.who.int/news-room/feature-stories/ten-threats-toglobal-health-in-2019. Acesso em: 08 maio 2020.

ZUCKERMAN, Ethan. Stop Saying Fake News, It's not Helping, My Heart is in Accra, 30 jan. 2017. 